\title{
Prostaglandin Transporter 0ATP2A1/SLCO2A1 Is Essential for Body Temperature Regulation during Fever
}

\author{
Yoshinobu Nakamura, ${ }^{1}$ TTakeo Nakanishi, ${ }^{1}$ Hiroaki Shimada, ${ }^{1,2}$ Junya Shimizu, ${ }^{1}$ Rika Aotani, ${ }^{1}$ Shio Maruyama, ${ }^{1}$ \\ Kei Higuchi, ${ }^{3}$ Takashi Okura, ${ }^{3}$ Yoshiharu Deguchi, ${ }^{3}$ and Ikumi Tamai ${ }^{1}$ \\ ${ }^{1}$ Faculty of Pharmaceutical Sciences, Institute of Medical, Pharmaceutical, and Health Sciences, Kanazawa University, Kanazawa 920-1192, Japan, ${ }^{2}$ Faculty \\ of Pharmacy, Kindai University, Osaka 577-8502, Japan, and 3Faculty of Pharma-Sciences, Teikyo University, Tokyo 173-8605, Japan
}

Prostaglandin $\mathrm{E}_{2}\left(\mathrm{PGE}_{2}\right)$ in the hypothalamus is a principal mediator of the febrile response. However, the role of organic anion transporting polypeptide $2 \mathrm{~A} 1$ (OATP2A1/SLCO2A1), a prostaglandin transporter, in facilitating this response is unknown. Here, we investigated the effect of Slco2al deficiency on the body core temperature (Tc) and on the $\mathrm{PGE}_{2}$ concentration in hypothalamus interstitial fluid $\left(C_{\text {isf }}\right)$ and CSF $\left(C_{\text {csf }}\right)$ of lipopolysaccharide (LPS; $100 \mu \mathrm{g} / \mathrm{kg}$, i.p.)-treated mice of both sexes. Slco2a1 ${ }^{-1-}$ mice did not develop a febrile

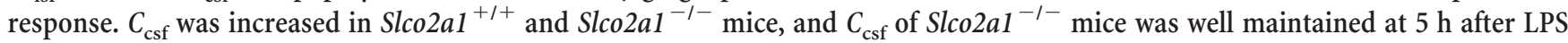
injection $(1160 \mathrm{pg} / \mathrm{ml})$ compared with Slco2a1 ${ }^{+/+}$mice $(316 \mathrm{pg} / \mathrm{ml})$. A microdialysis study revealed that $C_{\text {isf }}$ peaked at $2 \mathrm{~h}$ after LPS injection in Slco2a1 ${ }^{+/+}$mice $(841 \mathrm{pg} / \mathrm{ml})$, whereas the increase in $C_{\text {isf }}$ was negligible in Slco2a1 ${ }^{-1-}$ mice. The $\mathrm{PGE}_{2}$ plasma concentration in Slco2a $1^{-1-}$ mice $(201 \mathrm{pg} / \mathrm{ml})$ was significantly higher than that in Slco2a $1^{+/+}$mice $(54 \mathrm{pg} / \mathrm{ml})$ at $1 \mathrm{~h}$ after LPS injection, whereas the two groups showed similar $\mathrm{PGE}_{2}$ concentrations in the hypothalamus. Strong 0atp2a1 immunoreactivity was observed in F4/80-positive microglia and perivascular cells and in brain capillary endothelial cells. The changes in Tc and $C_{\text {isf }}$ seen in LPS-injected Slco2a1 ${ }^{+/+}$mice were partially attenuated in monocyte-/macrophage-specific Slco2a1 ${ }^{-1-}\left(\right.$ Slco2a $\left.{ }^{\mathrm{F} / \mathrm{Fl}} / L y s M^{\mathrm{Cre} /+}\right)$ mice. Thus, OATP2A1 facilitates the LPS-induced febrile response by maintaining a high level of $C_{\text {isf }}$, possibly by regulating $\mathrm{PGE}_{2}$ secretion from F4/80-positive glial cells and/or facilitating $\mathrm{PGE}_{2}$ transport across the blood-brain barrier. These findings suggest that 0ATP2A1 is a useful therapeutic target for neuroinflammation.

Key words: fever; hypothalamus; macrophage; 0ATP2A1; prostaglandin $\mathrm{E}_{2}$; transporter

Significance Statement

Fever is a physiological response caused by pyrogen-induced release of prostaglandin $\mathrm{E}_{2}\left(\mathrm{PGE}_{2}\right)$ in the hypothalamus, which plays a central role in regulating the set-point of body temperature. However, it is unclear whether the prostaglandin transporter OATP2A1/SLCO2A1 is involved in this response. We show here that LPS-induced fever is associated with increased $\mathrm{PGE}_{2}$ concentration in hypothalamus interstitial fluid $\left(C_{\text {isf }}\right)$, but not in $\operatorname{CSF}\left(C_{\mathrm{csf}}\right)$, by means of a microdialysis study in global Slco2a1-knockout mice and monocyte-/macrophage-specific Slco2a1-knock-out mice. The results suggest that OATP2A1 serves as a regulator of $C_{\text {isf }}$ in F4/80-positive glial cells. OATP2A1 was detected immunohistochemically in brain capillary endothelial cells and, therefore, may also play a role in $\mathrm{PGE}_{2}$ transport across the blood- brain barrier.

\section{Introduction}

Fever is a defensive response of the host to infection and is caused by exposure to pyrogens, which cause the secretion of inflamma-

Received Nov. 18, 2017; revised May 7, 2018; accepted May 11, 2018.

Author contributions: Y.N., T.N., and I.T. designed research; Y.N., T.N., H.S., J.S., R.A., and S.M. performed research; Y.N., T.N., K.H., T.O., and Y.D. contributed unpublished reagents/analytic tools; Y.N., T.N., H.S., J.S., R.A., S.M., and I.T. analyzed data; Y.N., T.N., and I.T. wrote the paper.

This work was supported by Grants-in-Aid for Scientific Research (KAKENHI, 15H04755 and 15K15181) from the Japan Society for the Promotion of Science. We thank Richard Steele for careful reading of this manuscript. We thank Drs. Ken-ichi Hosoya and Shin-ichi Akanuma at the University of Toyama for constructive comments and technical advice and for providing antibodies to detect Oatp2a1. We also thank Dr. Eiichi Hinoi and Maika Okamoto for assistance with measuring colorectal temperature. tory cytokines, including tumor necrosis factor $\alpha$ (TNF- $\alpha)$ and interleukin-1 $\beta$, from polymorphonuclear leukocytes (Roth and Blatteis, 2014). The role of prostaglandin $\mathrm{E}_{2}\left(\mathrm{PGE}_{2}\right)$ in this febrile response has been studied in mice lacking cyclooxygenase-2 (COX-2/PTGS2; Li et al., 1999; Steiner et al., 2005), microsomal PGE synthase-1 (PTGES; Engblom et al., 2003), or EP3 receptor

The authors declare no competing financial interests.

Correspondence should be addressed to Dr. Takeo Nakanishi, Faculty of Pharmaceutical Sciences, Institute of Medical, Pharmaceutical, and Health Sciences, Kanazawa University, Kakuma-machi, Kanazawa 920-1192, Japan. E-mail:nakanish@p.kanazawa-u.ac.jp.

DOI:10.1523/JNEUROSCI.3276-17.2018

Copyright $\odot 2018$ the authors $\quad 0270-6474 / 18 / 385584-12 \$ 15.00 / 0$ 
(PTGER3; Oka et al., 2003). These mice showed no temperature increase after systemic challenge with pyrogens such as lipopolysaccharide (LPS); therefore, $\mathrm{PGE}_{2}$ is considered a key mediator of the febrile response.

In rodents, the response to LPS is polyphasic, suggesting that more than one mechanism is involved. Inflammatory cytokines induce the synthesis of Cox-2 protein in brain endothelial cells (Cao et al., 1995; Laflamme et al., 1999; Engström et al., 2012), but this process is relatively slow, and the body core temperature (Tc) rises quickly in animals given intravenous injections of LPS; therefore, the febrile response at the early stage may require a rapid supply of $\mathrm{PGE}_{2}$ across the blood-brain barrier (BBB; Steiner et al., 2006). Moreover, the increase in Tc is correlated with the $\mathrm{PGE}_{2}$ level in CSF. $\mathrm{PGE}_{2}$ does not undergo catabolism in the brain of adult mammals, because the level of 15-hydroxyprostaglandin dehydrogenase (HPGD) expression in the brain is low (Nakano et al., 1972; Alix et al., 2008). Hence, extraction of $\mathrm{PGE}_{2}$ from CSF to blood is another determinant of Tc (Schuster, 2015). These facts suggest a role of membrane transporters in $\mathrm{PGE}_{2}$ transfer across the BBB and elimination from CSF.

Organic anion transporters (Oat), organic anion transporting polypeptides (Oatp), and multidrug resistance associated protein (Mrp) can transport $\mathrm{PGE}_{2}$ in brain capillary endothelial cells (BCECs) of rats (Akanuma et al., 2011). Among them, OATP2A1/SLCO2A1, also known as prostaglandin transporter, is a high-affinity carrier for prostanoids (Kanai et al., 1995) and plays a major role in $\mathrm{PGE}_{2}$ disposition in vivo (Chang et al., 2010; Nakanishi et al., 2015), as well as in the febrile response (Ivanov et al., 2003; Ivanov and Romanovsky, 2004). Oatp2a1 is expressed in primary cultures of rat cerebral endothelial cells (Kis et al., 2006) and is also expressed at the blood-CSF boundary, such as in the apical membranes of the choroid plexus (CP) in mice (Tachikawa et al., 2012) and subarachnoidal blood vessels in rats (Hosotani et al., 2015). Thus, it presumably facilitates $\mathrm{PGE}_{2}$ elimination from CSF into blood. OATP2A1 is also localized in neurons, microglia, and astrocytes in the human brain (Choi et al., 2008). We have shown that OATP2A1 is involved in $\mathrm{PGE}_{2}$ secretion from several types of cells including macrophages (Shirasaka et al., 2013; Shimada et al., 2015; Kasai et al., 2016). Since microglia are brain-resident macrophages, they could be a source of $\mathrm{PGE}_{2}$ associated with brain inflammation and the febrile response.

In the present study, we aimed to evaluate the role of OATP2A1 in $\mathrm{PGE}_{2}$ disposition in the brain and to establish whether it contributes to the development of the febrile response. For this purpose, we challenged globally Slco2a1deficient (Slco2a1 ${ }^{-1-}$ ) and monocyte-/macrophage-specific Slco2a1-knock-out (Slco2a1 ${ }^{\mathrm{Fl} / \mathrm{Fl}} / \mathrm{LysM}^{\mathrm{Cre} /+}$ ) mice with LPS and monitored the resulting changes of colorectal temperature and $\mathrm{PGE}_{2}$ concentration in brain interstitial fluid (ISF) in the preoptic/anterior hypothalamic area. Our results indicate that OATP2A1 does influence the local disposition of $\mathrm{PGE}_{2}$ in the brain during the febrile response.

\section{Materials and Methods}

Materials. LPS from Escherichia coli O111:B4 was purchased from SigmaAldrich. Paraformaldehyde and suramin sodium were purchased from Wako Pure Chemical Industries. All other compounds and reagents were commercial products of reagent grade. Microdialysis guide cannulas and probes were purchased from CMA Microdialysis. Anti-mouse Oatp2a1 guinea pig antibody was a gift from Prof. Ken-ichi Hosoya (University of Toyama, Toyama, Japan).

Animals. Slco2a1 ${ }^{+/+}$and Slco2a1 ${ }^{-/-}$mice used in this study had a mixed B6;129 genetic background. Slco2a ${ }^{-1-}$ mice were generated in our laboratory (Nakanishi et al., 2015; Gose et al., 2016). Slco2al ${ }^{\mathrm{Fl} / \mathrm{Fl} /}$
$L y s M^{\mathrm{Cre} /+}$ mice were generated by crossing Slco $2 a 1^{\mathrm{F} / \mathrm{Fl}}$ mice, in which Slco2al exon 1 is flanked by loxP sequences, with Lysozyme (Lys) $M^{\text {Cre/+ }}$ mice, obtained from RIKEN Bioresource Center (RRID:IMSR_RBRC02302). Genotypes were confirmed by PCR using the following primers: for Slco2a1 exon 1: sense, 5' - AGGACCTGATAGGCAGCCAA-3' and antisense, 5' - CACAGCAGAGACCCAACAGA-3'; for Lysozyme M-Cre: sense, 5' - GCATTGCAGACTAGCTAAAGGCAG-3' and antisense, 5' CCCAGAAATGCCAGATTACG-3'. Male mice (weighing $32.1 \pm 5.6 \mathrm{~g}$ ) and female mice (weighing $24.5 \pm 4.3 \mathrm{~g}$ ) age $8-49$ weeks were used.

Male Wistar rats weighing 170-280 g were purchased from Japan SLC. All animals were allowed ad libitum access to food and water under a standard $12 \mathrm{~h}$ light/dark cycle (8:45 A.M. to 8:45 P.M. light) in a temperature- and humidity-controlled room $\left(24 \pm 1^{\circ} \mathrm{C}, 55 \pm 5 \%\right)$. All animal experiments were performed in accordance with the requirements of the Kanazawa University Institutional Animal Care and Use Committee (permit numbers AP-143148, AP-153511, AP-163750, and AP-183957).

LPS injection and measurement of colonic temperature in mice. Mice were administered LPS as a single intraperitoneal dose of $100 \mu \mathrm{g} / \mathrm{kg}$ in $150 \mu \mathrm{l}$ of physiological saline, and changes of Tc were monitored by measuring the colonic temperature at $60 \mathrm{~min}$ intervals with a rectal thermometer, TD320 (Shibaura Electronics) or KN-91 (Natsume Seisakusho). The effect of handling stress on Tc was assessed at $30 \mathrm{~min}$ after intraperitoneal injection, as reported previously (Romanovsky et al., 2005). Each mouse was given injections of LPS between 11:15 and 11:25 A.M. to avoid the effect of diurnal fluctuation of thermoregulation. After a rest period of at least 1 week, basal Tc was measured in the same mice after injection of the vehicle alone. At $5 \mathrm{~h}$ after injection, the mice were exsanguinated under deep anesthesia (with pentobarbital), and brain tissues were excised for qRT-PCR, Western blotting, or immunohistochemistry. The hypothalamus and cerebral cortex tissue were collected according to Glowinski's method (Glowinski and Iversen, 1966).

Effect of suramin on Tc in rats. Anesthetized rats were placed on a stereotaxic instrument. A hole was drilled in the skull, and a steel cannula (outside diameter, $0.5 \mathrm{~mm}$; inner diameter, $0.26 \mathrm{~mm}$ ) was implanted close to the lateral hypothalamus and fixed to the skull with dental cement. The coordinates for the hypothalamus were $-0.1 \mathrm{~mm}$ anterior to bregma, $0.6 \mathrm{~mm}$ lateral, and $7.0 \mathrm{~mm}$ ventral to the skull (Paxinos and Watson, 2013). After 1 week, rats were given LPS ( $100 \mu \mathrm{g} / \mathrm{kg}$, i.p., in 500 $\mu \mathrm{l}$ of physiological saline), and the colonic temperature was measured with a rectal thermometer (KN-91). A 30 gauge needle connected to a microsyringe was inserted into the implanted steel cannula $1 \mathrm{~h}$ before the LPS injection, and $2 \mu \mathrm{l}$ of vehicle or suramin solution in physiological saline $(700 \mu \mathrm{M})$ was injected using a microsyringe pump (CMA102; CMA Microdialysis AB) over 2 min.

Microdialysis. Anesthetized mice were placed on a stereotaxic instrument. A hole was drilled in the skull, and a microdialysis guide cannula (CMA7 guide cannula) was implanted close to the lateral hypothalamus and fixed to the skull with dental cement. The coordinates for the hypothalamus were $0.9 \mathrm{~mm}$ anterior to bregma, $0.1 \mathrm{~mm}$ lateral, and $4.5 \mathrm{~mm}$ ventral to the skull (Paxinos and Franklin, 2012). The next day, a microdialysis probe (CMA7; membrane length, $1 \mathrm{~mm}$; CMA Microdialysis) was inserted into the hypothalamus. Five days later, Krebs-Ringer phosphate buffer (KRPB; $120 \mathrm{~mm} \mathrm{NaCl}, 2.4 \mathrm{~mm} \mathrm{KCl}, 1.2 \mathrm{~mm} \mathrm{CaCl}_{2}, 1.2 \mathrm{~mm}$ $\mathrm{MgSO}_{4}, 0.9 \mathrm{~mm} \mathrm{NaH} \mathrm{PO}_{4}, 1.4 \mathrm{~mm} \mathrm{Na}_{2} \mathrm{HPO}_{4}, \mathrm{pH}$ 7.4) was perfused through the probe at a constant flow rate of $2 \mu \mathrm{l} / \mathrm{min}$. After LPS treatment $(100 \mu \mathrm{g} / \mathrm{kg}$, i.p.), the dialysate was collected every $1 \mathrm{~h}$. The experimental conditions were such that the animals could move freely. $\mathrm{PGE}_{2}$ in the dialysate was determined by liquid chromatography-mass spectrometry/mass spectrometry (LC-MS/MS) as described in our previous report (Gose et al., 2016). At the end of the experiment, the mice were exsanguinated under deep anesthesia, the microdialysis probe was removed, and brain tissues were collected. Placement of the inserted probe near the hypothalamus was confirmed by histological examination. The isolated probe was immediately placed in KRPB containing $10 \mathrm{ng} / \mathrm{ml} \mathrm{PGE}_{2}$, and $\mathrm{KRPB}$ was perfused at the flow rate of $2 \mu \mathrm{l} / \mathrm{min}$ for $1 \mathrm{~h}$. The in vitro relative recovery (RR) was determined as follows: $\mathrm{RR}(\%)=$ $C_{\mathrm{d} \text {,vitro }} / C_{\mathrm{r}} \times 100$, where $C_{\mathrm{d} \text {,vitro }}$ is the dialysate concentration of $\mathrm{PGE}_{2}$ and $C_{\mathrm{r}}$ is the reservoir concentration of $\mathrm{PGE}_{2}$ in KRPB. The concentra- 
tion of $\mathrm{PGE}_{2}$ in the interstitial fluid $\left(C_{\mathrm{isf}}\right)$ was approximated by dividing the $\mathrm{PGE}_{2}$ concentration in the dialysate collected from mice $\left(C_{\mathrm{d} \text {,vivo }}\right)$ by $\mathrm{RR}$, as follows: $C_{\text {isf }}=C_{\mathrm{d} \text {,vivo }} / \mathrm{RR}$.

$P G E_{2}$ quantification. CSF, blood, hypothalamic tissue, and cerebral cortex tissue were collected under anesthesia from mice at 1 and/or $5 \mathrm{~h}$ after LPS injection ( $100 \mu \mathrm{g} / \mathrm{kg}$ or $20 \mathrm{mg} / \mathrm{kg}$, i.p.). Blood was centrifuged at $2000 \times g$ at $4^{\circ} \mathrm{C}$ for $10 \mathrm{~min}$ to obtain plasma. The collected samples were frozen and stored at $-80^{\circ} \mathrm{C}$ until use. Brain tissues were homogenized by sonication (QSonica). Eicosanoids were extracted from the homogenate $(10 \mathrm{mg})$, from CSF $(5 \mu \mathrm{l})$, or from plasma (200 $\mu \mathrm{l})$ containing $\mathrm{d}_{4}-\mathrm{PGE}_{2}$ as an internal standard with a solid-phase cartridge (Oasis MAX; Waters) according to the manufacturer's protocol. The eicosanoids were eluted with $0.1 \%$ formic acid/acetonitrile and quantified with an LC-MS/MS system consisting of an LCMS8050 triple quadrupole mass spectrometer (Shimadzu) coupled with an LC-30AD ultra-fast liquid chromatography system (Shimadzu). The flow rate of the mobile phase was $0.4 \mathrm{ml} / \mathrm{min}$, and the injection volume was set as $30 \mu \mathrm{l}$. CAPCELL PAK IF2 (C18, $2.1 \mathrm{~mm}$ inner diameter $\times 100 \mathrm{~mm}, 2 \mu \mathrm{m}$; Shiseido) was used as an analytical column. Samples were kept at $4^{\circ} \mathrm{C}$ during the analysis. Electrospray negative ionization was used, and the mass transitions were monitored at $m / z 351.1 / 271.1$ for $\mathrm{PGE}_{2}$ and $\mathrm{m} / z$ 355.1/275.2 for $\mathrm{d}_{4}-\mathrm{PGE}_{2}$. Analyst software Lab Solution LCMS was used for data manipulation.

Immunohistochemistry. Excised brain tissues were fixed overnight with $4 \%$ paraformaldehyde at $4^{\circ} \mathrm{C}$. Frozen and paraffin-embedded sections were prepared from mouse brains. The sections were treated with $5 \%$ nonfat dry milk in PBS, pH 7.4, or Blocking One Histo (Nacalai Tesque) for $1 \mathrm{~h}$ or $10 \mathrm{~min}$, respectively, at room temperature and incubated overnight at $4^{\circ} \mathrm{C}$ with guinea pig anti-Oatp2al IgG (1:150 dilution), rabbit anti-Oatp2a1 IgG (1:400 dilution; Bioss Antibodies), rat antiF4/80 IgG (1:100 dilution; AbD Serotec; RRID:AB_2098196), rat antiCD34 IgG (1:50 dilution; BD Biosciences; RRID:AB_395015), rabbit anti-Cox-2 IgG (1:100 dilution; Cell Signaling Technology; RRID: AB_2571729), or rabbit anti-Cox-1 IgG (1:100 dilution; Cell Signaling Technology; RRID:AB_10860249). The sections were further incubated with biotinylated secondary antibodies (1:200-400 dilution) and with horseradish peroxidase-conjugated streptavidin (Thermo Fisher Scientific). After 3,3'-diaminobenzidine staining, the sections were examined under a light microscope. For fluorescence immunohistochemistry, the primary antibody was labeled with the appropriate IgG linked to Alexa Fluor 594 or Alexa Fluor 488 (Life Technologies). Nuclei were counterstained with Hoechst 33342 (Life Technologies), and the sections were mounted with Vectashield (Vector Laboratories). The sections were examined with an LSM710 confocal laser microscope (Carl Zeiss) or a conventional BZ-9000 fluorescence microscope (Keyence).

Oatp2al was quantified in brain sections of Slco2a1 ${ }^{\mathrm{F} / \mathrm{Fl}}$ and Slco $2 a 1^{\mathrm{FlFl}} / \mathrm{LysM}^{\mathrm{Cre} /+}$, and results are shown as mean values of $32 \mathrm{ran}-$ domly selected images from four independent mice in each group. Glial cells, including microglia and macrophage-derived perivascular cells, were identified based on F4/80 immunofluorescence.

$q R T-P C R$. Total RNA was extracted from tissues and cells of interest using RNAiso Plus (Takara Bio) and reverse-transcribed with a highcapacity cDNA reverse transcription kit (Applied Biosystems). mRNA expression levels of murine Slco2a1, Cox-2/Ptgs2, prostaglandin E synthase (mPges-1/Ptges), Ep3/Ptger3, and C-X-C motif chemokine 10 ( Cxcl10) were quantified by qRT-PCR with the following primers: for Slco2a1: sense, 5' -GGACGGTGCCCATTCAGCCA-3' and antisense, 5' AGGTTCACTGTAGCCGTGTCCA-3'; for Ptgs2: sense, 5' -ATGAGTAC CGCAAACGCTTC- $3^{\prime}$ and antisense, $5^{\prime}$-TCTGGACGAGGTTTTTC CAC-3'; for Ptges: sense, 5'-GCACACTGCTGGTCATCAAG-3' and antisense, 5' -ATGAGTACACGAAGCCGAGG-3'; for Ptger3: sense, 5' ACCATCAAAGCCCTGGTGTC-3' and antisense, 5' -TGTGTCTTGC ATTGCTCAACC-3'; for Cxcl10: sense, 5' -CAAGTGCTGCCGTCATTT TC-3' and antisense, 5'-TCAACACGTGGGCAGGATAG-3'. mRNA expression was normalized with respect to hypoxanthine-guanine phosphoribosyltransferase (Hprt) or glyceraldehyde 3-phosphate dehydrogenase (Gapdh) expression as described in our previous report (Nakanishi et al., 2015). Ct values of $<31$ in the real-time PCR analysis were considered as representing significant expression of mRNA.
Western blot analysis. Western blot analysis was performed as described previously (Nakanishi et al., 2015). Excised hypothalamic tissue was homogenized by sonication (QSonica) and lysed in RIPA buffer (150 mm sodium chloride, $1 \%$ Nonidet P-40, $0.5 \%$ sodium deoxycholate, $0.1 \%$ SDS, and $50 \mathrm{~mm}$ Tris, $\mathrm{pH} 8.0$ ) containing protease inhibitor cocktail (Nacalai Tesque). Samples were centrifuged at $10,000 \times g$ at $4^{\circ} \mathrm{C}$ for $10 \mathrm{~min}$, and protein concentration was determined with a Bio-Rad protein assay kit. An aliquot of tissue homogenate $(20 \mu \mathrm{g})$ was separated by SDS-PAGE (10\%) and electrotransferred onto polyvinylidene difluoride membrane (EMD Millipore). The membrane was incubated with 5\% nonfat dry milk in TBS-T [Tris-buffered saline containing $0.1 \%(\mathrm{v} / \mathrm{v})$ Tween 20] for $1 \mathrm{~h}$ at room temperature; incubated overnight at $4^{\circ} \mathrm{C}$ with primary antibody against Cox-2 and Cox-1 (each 1:500 dilution; Cell Signaling Technology), 15-Pgdh (1:400 dilution; Cayman Chemical; RRID:AB_327883), or Gapdh (1:5000 dilution; Cell Signaling Technology); and further incubated with horseradish peroxidase-conjugated secondary antibody (1:1000-5000 dilution; Thermo Fisher Scientific) for $1 \mathrm{~h}$ at room temperature. Bands were detected by electrochemical luminescence assay (Wako Pure Chemical Industries) and quantified using a CS analyzer (ATTO).

Quantitative PCR for genomic DNA. Genomic DNA was isolated from excised tissues and peritoneal macrophages (collected from thioglycollate-treated mice) using phenol/chloroform/isoamyl alcohol (Wako Pure Chemical Industries). Slco2a1 allele was quantified by quantitative PCR using the following primers: sense, $5^{\prime}$-CCGCTCGGTCTTCAACA ACA-3' and antisense, 5' -ACTGGCCTCATCGACGTCCTA-3' .

Serum levels of inflammatory cytokines in mice. Approximately $100 \mu \mathrm{l}$ of blood was drawn from a tail vein at $2 \mathrm{~h}$ after LPS injection $(100 \mu \mathrm{g} / \mathrm{kg})$, allowed to clot at room temperature for $2 \mathrm{~h}$, and centrifuged at $2000 \times g$ at $4^{\circ} \mathrm{C}$ for $20 \mathrm{~min}$ to obtain serum. TNF- $\alpha$ was determined with an immunoassay kit (R\&D Systems) according to the manufacturer's protocol. Optical density at $420 \mathrm{~nm}$ was measured with a micro-plate reader, ARVO MX (PerkinElmer Life Sciences). The procedure was repeated after injection of the vehicle alone in the same mice 1-4 weeks later.

Experimental design and statistical analysis. Mice were assigned to experimental groups so that the groups were well matched for age and sex. The numbers of animals used in this study are given in the figure legends. All data are expressed as mean \pm SEM of at least three experiments, as indicated, and statistical analysis was performed with Student's $t$ test. The criterion of significance was $p<0.05$.

\section{Results}

\section{Impact of genetic deletion or pharmacological inhibition of Oatp2a1 on LPS-induced febrile response}

To examine the effect of loss of Slco2al on the increase of $\mathrm{T}_{c}$ induced by LPS $(100 \mu \mathrm{g} / \mathrm{kg})$, we monitored colonic temperature in Slco2a1 $1^{+/+}$and Slco2a1 ${ }^{-/-}$mice. There was no significant difference between the Tc values of Slco $2 a 1^{+/+}$and Slco $2 a 1^{-1-}$ mice treated with physiological saline (PS) at any time point examined, suggesting that OATP2A1 does not affect the circadian rhythm of basal body temperature. In LPS-treated Slco2a1 ${ }^{+/+}$ mice, Tc began to increase at $2 \mathrm{~h}$ and reached a plateau by $5 \mathrm{~h}$, whereas the Tc values of LPS-treated Slco2a1 ${ }^{-/-}$mice remained close to basal levels (Fig. 1A). The difference in Tc between LPStreated Slco2a1 ${ }^{+/+}$and Slco2al ${ }^{-/-}$mice was greatest at $7 \mathrm{~h}$, reaching $0.7^{\circ} \mathrm{C}\left(37.8^{\circ} \mathrm{C}\right.$ vs $37.1^{\circ} \mathrm{C}, p=0.009$; Fig. $\left.1 \mathrm{~A}\right)$.

We also examined the effect of intracerebral injection of suramin, which is a high-affinity inhibitor of OATP2A1 (Kamo et al., 2017), in rats. No significant increase in Tc was observed in the PS/PS control group, whereas in the LPS/PS group, Tc continued to rise for $5 \mathrm{~h}$ (Fig. $1 B$ ). In the LPS/suramin group, Tc rose initially and then fell to the basal level at $5 \mathrm{~h}$. Rats in the LPS/ suramin group exhibited significantly lower Tc $\left(37.3^{\circ} \mathrm{C}\right) \mathrm{com}-$ pared with those of the LPS/PS group $\left(38.5^{\circ} \mathrm{C}\right)$ at $6 \mathrm{~h}$ after LPS injection ( $p=0.001$; LPS/PS vs LPS/suramin). 

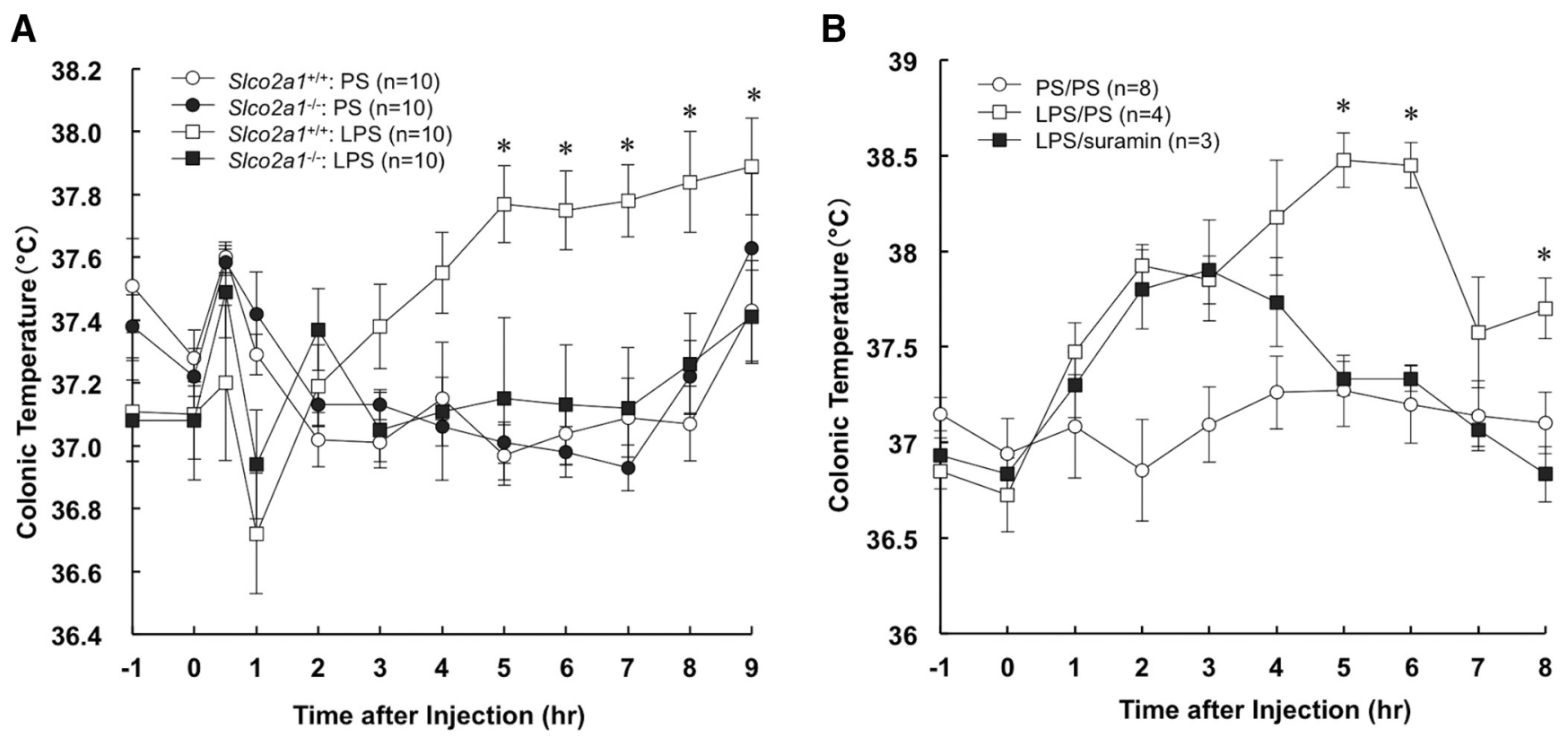

Figure 1. Contribution of OATP2A1 to the febrile response after LPS challenge. A, Tc was monitored in Slco2a ${ }^{+/+}$(open) and S/co2a ${ }^{-/-}$(filled) mice treated with LPS (100 $\mu \mathrm{g} / \mathrm{kg}$; Square) or vehicle alone (circle). $n=10$ for each group. $\boldsymbol{B}$, Tc was monitored in rats treated with LPS (100 $\mu \mathrm{g} / \mathrm{kg}$, i.p.; square) or PS (circle) and microinjected to the hypothalamus with suramin (filled) or PS (open). $n=4$ for LPS/PS; $n=3$ for LPS/suramin; $n=8$ for PS/PS. Each point represents the mean value \pm SEM. The asterisk indicates statistically significant differences $(p<0.05)$ between SICO2a ${ }^{+/+}:$LPS and S/C02a1 ${ }^{-1-}:$ LPS $(\boldsymbol{A})$ and between LPS/PS and LPS/suramin $(\boldsymbol{B})$ by Student's $t$ test.

\section{Expression of $\mathrm{PGE}_{2}$ signaling-related and inflammatory genes} in the hypothalamus

To examine whether Slco2al deficiency affects the inflammatory response, we measured the mRNA levels of the inducible genes Ptgs2 and Cxcl10; Cxcl10 is an established inflammation marker in the hypothalamus (Wilhelms et al., 2014). The mRNA expression levels of both genes were significantly increased at $1 \mathrm{~h}$ after LPS treatment in both Slco2a1 ${ }^{+/+}($Ptgs $2, p=0.002$; Cxcl10, $p=$ $0.006)$ and Slco2a1 ${ }^{-1-}($ Ptgs $2, p=0.017 ;$ Cxcl10, $p=0.028$; Fig. $2 A, B)$. Cxcl10 mRNA was further elevated at $5 \mathrm{~h}$. However, there was no significant difference in expression of these mRNAs between Slco2a1 $1^{+/+}$and Slco2a1 $1^{-/-}$mice at any time during the test period, implying that both strains respond similarly to the inflammatory stimulus. In addition, no significant change was detected in the expression of Cox-2 ( $p=0.419$; Fig. $2 C)$, Cox-1 $(p=0.745$; Fig. $2 D)$, or 15 -Pgdh $(p=0.801$; Fig. $2 E)$ in the hypothalamus between Slco2a ${ }^{+/+}$and Slco2a ${ }^{-/-}$mice at $5 \mathrm{~h}$ after LPS treatment. Loss of Slco2a1 also did not affect the mRNA expression of Ptges ( $p=0.282$; Fig. $2 F)$ or $\operatorname{Ptger} 3$ ( $p=0.823$; Fig. $2 G)$. These results suggest that the influence of Slco2al on the increase of Tc is not mediated by changes in the expression of any of these genes (Fig. 1A).

\section{Brain disposition and plasma concentration of $\mathrm{PGE}_{2}$}

Since the increase in Tc appears to be associated with raised $\mathrm{PGE}_{2}$ levels in CSF, we measured the $\mathrm{PGE}_{2}$ concentration in the CSF of Slco2al ${ }^{+/+}\left(C_{\mathrm{csf}, \mathrm{WT}}\right)$ and Slco2a1 ${ }^{-l-}\left(C_{\mathrm{csf}, \mathrm{KO}}\right)$ mice. The PGE concentration was markedly increased at $1 \mathrm{~h}$ after LPS injection and reached 1118 and $1182 \mathrm{pg} / \mathrm{ml}$, respectively (Fig. $3 A$ ). $C_{\mathrm{csf}, \mathrm{WT}}$ was decreased to the basal level at $5 \mathrm{~h}(316 \mathrm{pg} / \mathrm{ml})$; however, $C_{\text {csf,KO }}$ remained almost unchanged $(1160 \mathrm{pg} / \mathrm{ml})$, being 3.7-fold higher than $C_{\mathrm{csf}, \mathrm{WT}}$ at $5 \mathrm{~h}(p=0.048$; Fig. $3 A)$. Since $C_{\mathrm{csf}, \mathrm{KO}}$ was unrelated to changes in Tc of Slco2a1 ${ }^{-1-}$ mice (Fig. $1 A$ ), we measured the $\mathrm{PGE}_{2}$ concentration in ISF at the hypothalamus $\left(C_{\text {isf }}\right)$ by means of a microdialysis technique. There was no significant difference in the RR of $\mathrm{PGE}_{2}$ between Slco2a1 ${ }^{+/+}(1.8 \pm$
$0.2 \%)$ and Slco $2 a 1^{-1-}(2.0 \pm 0.2 \%, p=0.389)$ mice. The time course of $C_{\text {isf }}$ in Slco2a $1^{+/+}$mice $\left(C_{\text {isf,WT }}\right)$ was slightly biphasic. The maximum $\mathrm{PGE}_{2}$ concentration of Slco2a1 ${ }^{+/+}$mice $\left(C_{\text {isf,max,WT }}\right)$ was $841 \mathrm{pg} / \mathrm{ml}$, and $C_{\text {isf,wT }}$ was significantly higher than $C_{\text {isf }}$ of Slco2a1 ${ }^{-l-}$ mice $\left(C_{\mathrm{isf}, \mathrm{KO}}\right)$ for $5 \mathrm{~h}$ after LPS injection $(p<0.05$; Fig. $3 B)$. In contrast, $C_{\text {isf,KO }}$ was only slightly increased in Slco2a1 ${ }^{-1-}$ mice, with $C_{\text {isf,max,KO }}$ of $380 \mathrm{pg} / \mathrm{ml}$, which was not significantly different from the basal level $\left(C_{\text {isf,KO,5 h, }} 246 \mathrm{pg} / \mathrm{ml}\right.$, $p=0.213)$. Moreover, the $\mathrm{PGE}_{2}$ concentration in the hypothalamus $\left(C_{\text {hyp }}\right)$ was similar in Slco2a1 ${ }^{+/+}$and Slco2a1 ${ }^{-l-}$ mice; $C_{\text {hyp,WT }}$ and $C_{\text {hyp,Ko }}$ were 12.9 and $12.1 \mathrm{pg} / \mathrm{mg}$ tissue, respectively $(p=0.833$; Fig. $3 C) . C_{\text {hyp,wT }}$ was unaffected by LPS treatment,

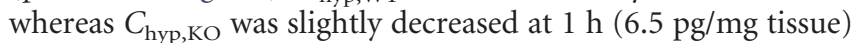
but was similar to $C_{\mathrm{hyp}, \mathrm{wT}}$ at $5 \mathrm{~h}(9.9 \mathrm{pg} / \mathrm{mg}$ tissue $)$. Next, the $\mathrm{PGE}_{2}$ concentration in the cerebral cortex $\left(C_{\text {cor }}\right)$ was determined. Basal $C_{\text {cor,WT }}(13.1 \mathrm{pg} / \mathrm{mg}$ tissue $)$ and $C_{\text {cor,KO }}(14.3 \mathrm{pg} / \mathrm{mg}$ tissue $)$ were similar to basal $C_{\text {hyp,WT }}(12.9 \mathrm{pg} / \mathrm{mg}$ tissue $)$ and $C_{\text {hyp,KO }}$ (12.1 pg/mg tissue), respectively. As with $C_{\text {hyp }}$, LPS $(100 \mu \mathrm{g} / \mathrm{kg})$ had no marked effect on $C_{\text {cor }}$ (Fig. $3 D$ ); however, a higher dose of LPS $\left(20 \mathrm{mg} / \mathrm{kg}\right.$ ) elevated $C_{\text {cor }, 5 \mathrm{~h}}$ and $C_{\text {hyp }, 5 \mathrm{~h}}$ despite the Slco2al deficiency (Fig. $3 C, D$ ), in agreement with a previous report (Nomura et al., 2011). These results suggest that Slco2al $1^{+/+}$and Slco2a1 ${ }^{-1-}$ mice have similar abilities to produce PGE 2 . Finally, the $\mathrm{PGE}_{2}$ plasma concentration $\left(C_{\mathrm{p}}\right)$ in Slco2a1 ${ }^{-1-}$ mice $(201$ $\mathrm{pg} / \mathrm{ml})$ was significantly higher than that of Slco $2 a 1^{+/+}$mice $(54$ $\mathrm{pg} / \mathrm{ml})$ at $1 \mathrm{~h}$ after LPS treatment $(p=0.007$; Fig. $3 E)$.

\section{Immunostaining of Oatp2a1 in mouse brain}

Oatp2a1 localization in the brain was studied by means of immunohistochemistry in mice challenged with LPS $(100 \mu \mathrm{g} / \mathrm{kg})$. As previously reported, Oatp2a1 was detected in the epithelial cells of the CP (Fig. 4A) in Slco2a1 ${ }^{+/+}$mice. Parenchymal cells, including glial cells and nerve cells, in the region of the hypothalamus were stained (Fig. 4B), and immunoreaction was also detected around blood vessels and at the axial fibers of nerve cells in the cerebral cortex (Fig. 4C,D). Staining was negligible in 


\section{A Ptgs2 (Cox-2)}

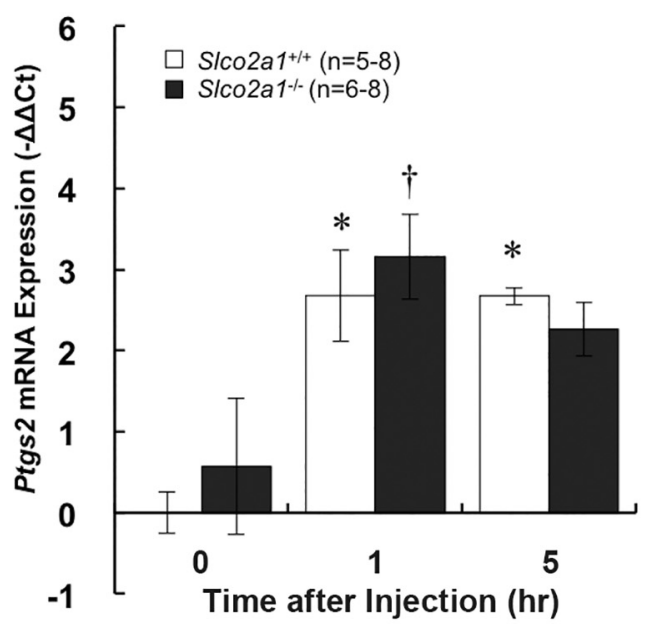

B Cxcl10

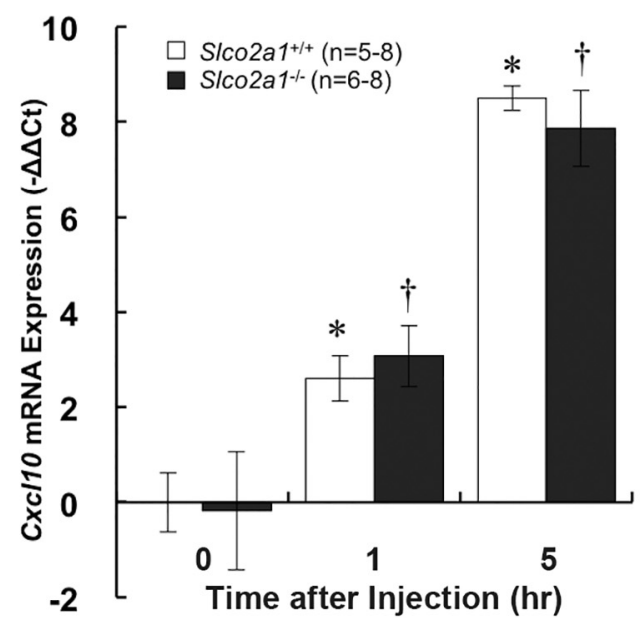

C Cox-2/Ptgs2

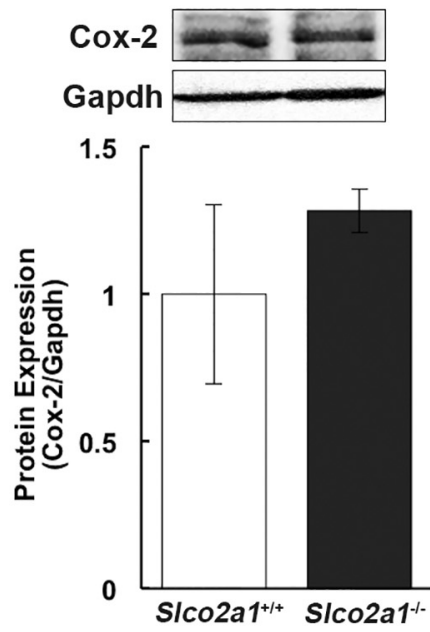

D Cox-1/Ptgs1
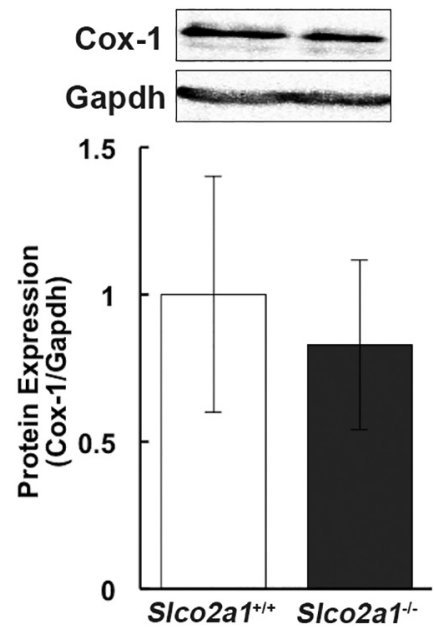

E 15-Pgdh/Hpgd
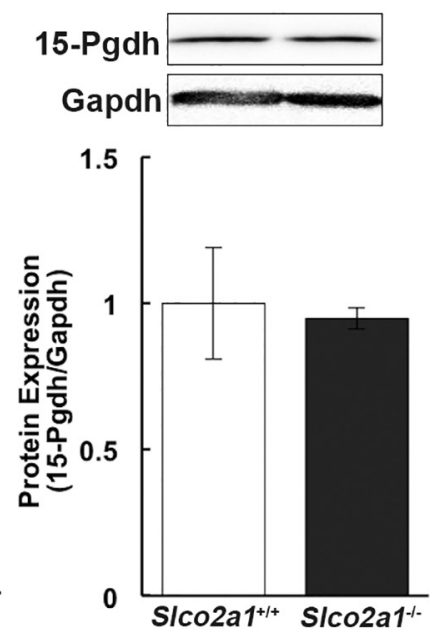

F Ptges (mPges-1)

G Ptger3 (Ep3)
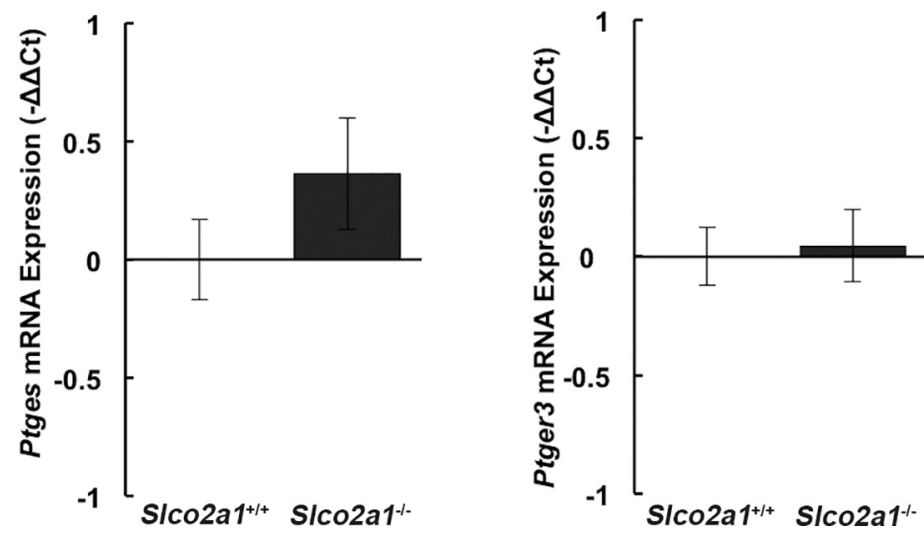

Figure 2. Effect of LPS on expression of PGE signaling-related and inflammatory genes in S/co2a $1^{-1-}$ mice. $A, B$, mRNA expression of Ptgs2 and $C x c 110$ in hypothalamic tissue of $L P S$ (100 $\mu \mathrm{g} / \mathrm{kg})$-treated S/co2a ${ }^{+1+}(n=5-8)$ and Slco2a $1^{-1-}(n=6-8)$ mice. C-G, Cox-2, Cox-1, and 15-Pgdh expression evaluated by Western blotting (C-E) and mRNA expression of Ptges and Ptger3 evaluated by qRT-PCR $(\boldsymbol{F}, \boldsymbol{G})$ in hypothalamic tissue from LPS-treated mice at $5 \mathrm{~h}$ after LPS injection (100 $\mu \mathrm{g} / \mathrm{kg})$. Band intensities of interest were normalized with that of Gapdh as shown in bar graphs at the bottom $(\boldsymbol{C}-\boldsymbol{E})$. Each bar represents the mean \pm SEM ( 3 independent animals). The asterisk and dagger indicate statistically significant differences ( $p<0.05)$ from LPS $0 \mathrm{~h}$ in SICO2a1 ${ }^{+1+}$ and SICO2a1 ${ }^{-1-}$ mice by Student's $t$ test. 


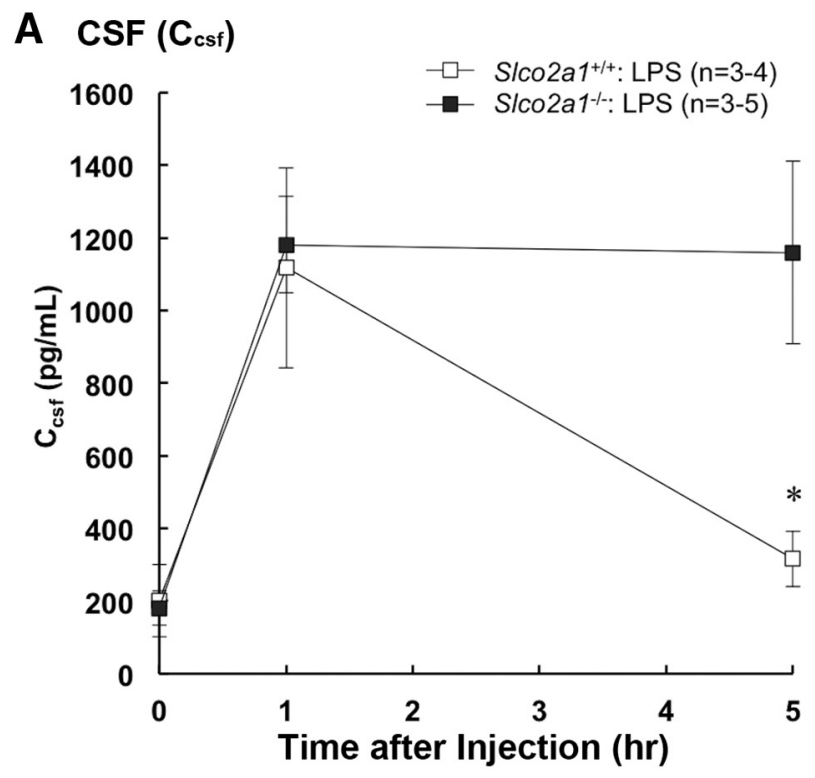

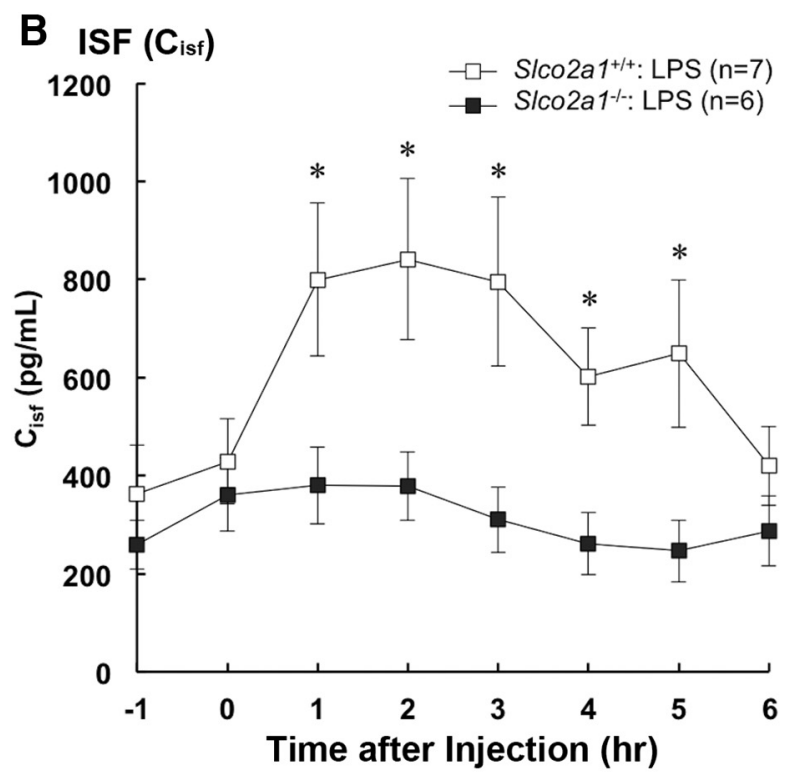

\section{Hypothalamus ( $\left.C_{\text {hyp }}\right)$}

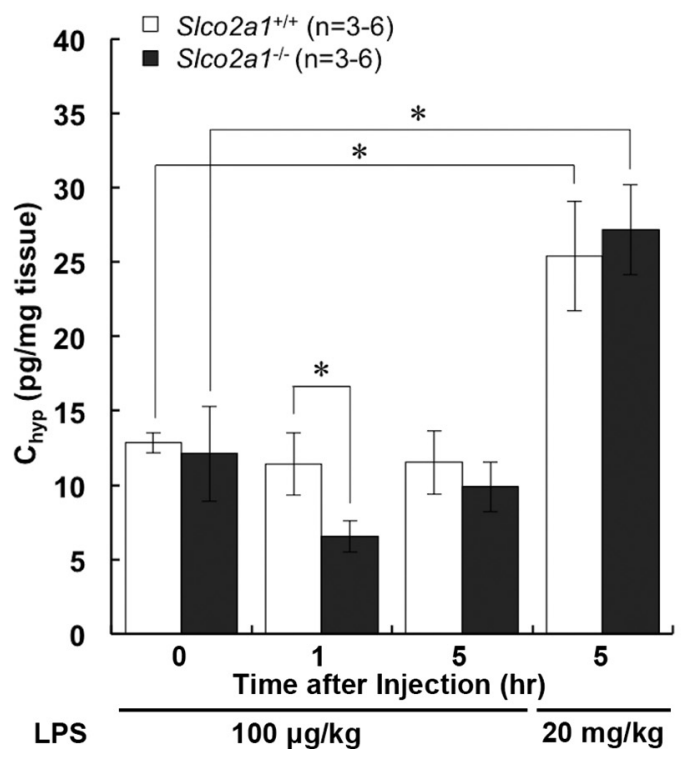

D Cerebral cortex ( $\left.\mathrm{C}_{\mathrm{cor}}\right)$

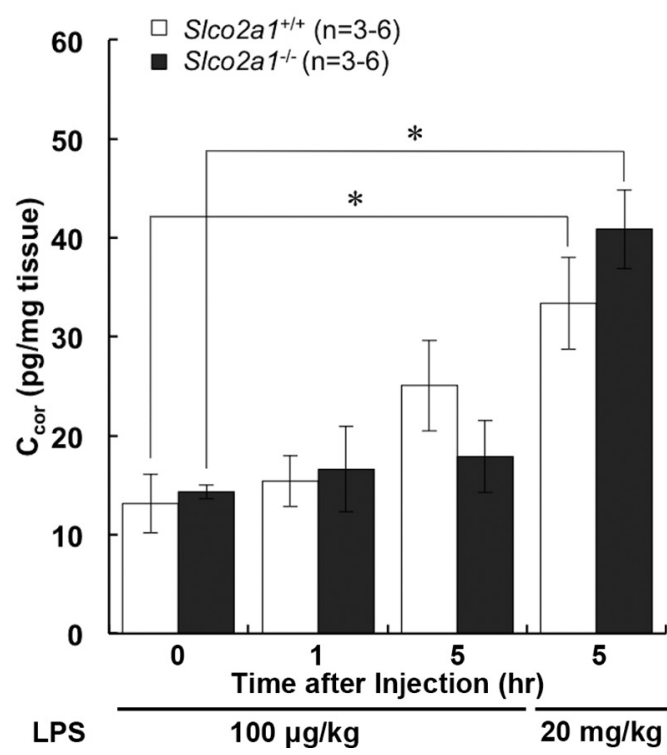

E Plasma $\left(C_{p}\right)$

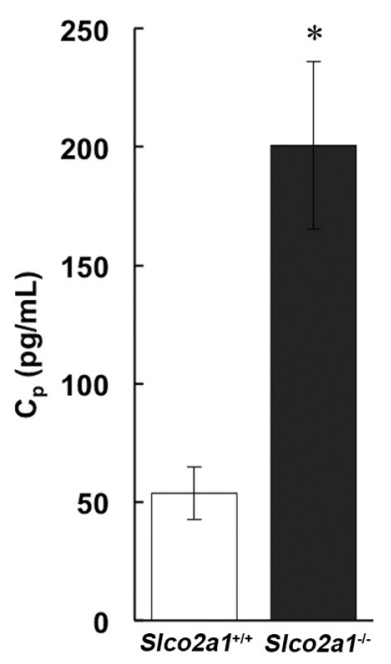

Figure 3. Effect of S/co2a1 deficiency on PGE disposition in the brain. $\boldsymbol{A}$, Time course of $C_{\mathrm{csf}}$ in S/co2a1 ${ }^{+/+}$(open, $\left.n=3-4\right)$ and S/co2a1 ${ }^{-1-}$ (filled, $\left.n=3-4\right)$ mice treated with LPS (100

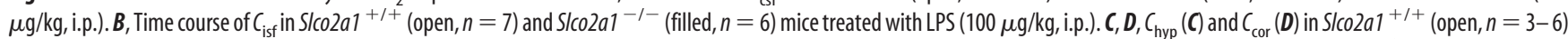
and S/co2a1 ${ }^{-1-}$ (filled, $\left.n=3-6\right)$ mice treated with LPS (100 $\mu \mathrm{g} / \mathrm{kg}$ or $20 \mathrm{mg} / \mathrm{kg}$, i.p.). Tissue concentration was normalized by wet weight of tissue. $\boldsymbol{E}, C_{\mathrm{p}}$ in S/co2a ${ }^{+/+}$(open, $\left.n=4\right)$ and SIco2a ${ }^{-1-}$ (filled, $\left.n=4\right)$ mice at $1 \mathrm{~h}$ after LPS treatment $(100 \mu \mathrm{g} / \mathrm{kg}$, i.p.). Each point or bar represents the mean \pm SEM. The asterisk indicates statistically significant differences $(p<0.05)$ by Student's $t$ test.

Slco2a $1^{-1-}$ mice, confirming the specificity of the antibody for Oatp2al (Fig. $4 A-D$ ). Furthermore, Oatp2al was detected in BCECs of Slco2a1 ${ }^{+/+}$mice but not in BCECs of Slco $2 a 1^{-1-}$ mice (Fig. 4E). Since perivascular macrophages and endothelial cells are major sources of $\mathrm{PGE}_{2}$ in the brain (Saper et al., 2012), we examined the colocalization of Oatp2a1 with macrophage marker F4/80 and endothelial cell marker CD34 in the perivascular region by means of fluorescence immunohistochemistry of frozen brain sections. Fluorescence attributable to anti-Oatp2a1 antibody was partially colocalized with that caused by anti-CD34 antibody (Fig. $4 F$ ), as well as with that attributable to F4/80 in perivascular cells (Fig. 4G) and in glial cells (presumably microglia; Fig. 4H). Oatp2a1 was not detected in corresponding sections derived from Slco $2 a 1^{-/-}$mice (Fig. $4 F-H$ ). Cox-2 staining was detected not only along blood vessels (Fig. 4I) but also on brain parenchymal cells (Fig. $4 J$ ) in mice challenged with LPS (100 $\mu \mathrm{g} / \mathrm{kg}$ ). No staining was observed in the absence of the primary antibody (Fig. $4 I, J$ ). Moreover, Cox-1/Ptgs 1 was detected in F4/80-positive cells in the hypothalamus (Fig. $4 K$ ).

Contribution of Oatp2a1 in macrophages to the LPS-induced febrile response

To assess the contribution of Oatp2a1 in F4/80-positive cells to the febrile response, we used Slco2a $1^{\mathrm{Fl} / \mathrm{Fl}} / L y s M^{\mathrm{Cre} /+}$ mice. In Slco $2 a 1^{\mathrm{Fl} / \mathrm{Fl}} / L y s M^{\mathrm{Cre} /+}$-derived peritoneal macrophages, floxed alleles of Slco2al were reduced to $\sim 10 \%$ of those in Slco $2 a 1^{\mathrm{Fl} / \mathrm{Fl}}$ mice $(p=0.001)$, whereas no significant change was observed in other tissues (Fig. 5A). Slco2a1 mRNA expression was signifi- 
A Choroid plexus (CP)

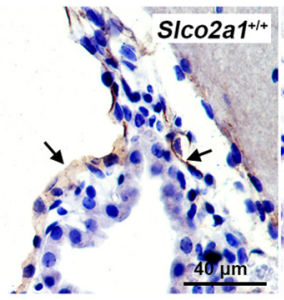

B Brain parenchyma (Hypothalamus)

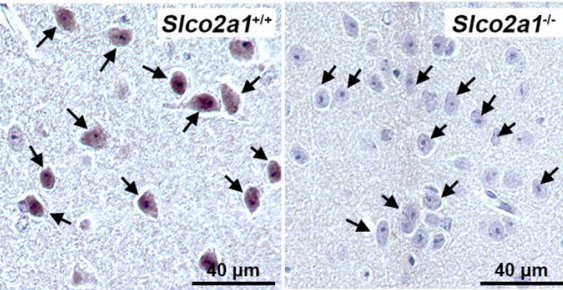

\section{Blood vessels (Hypothalamus)}
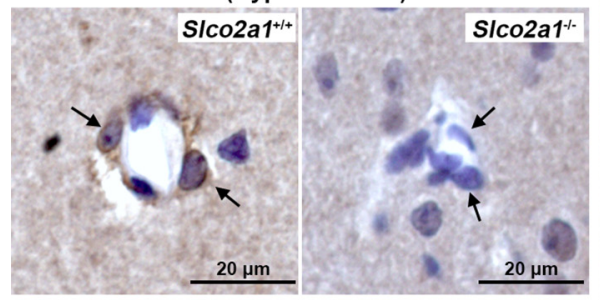

D Nerve cells (Cerebral cortex)

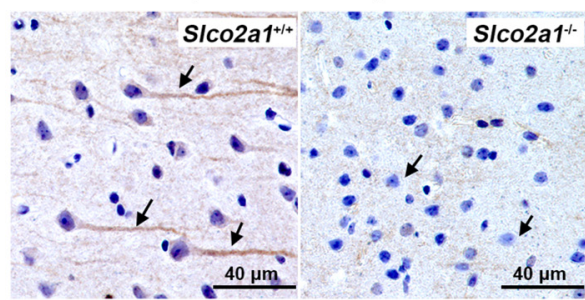

E Capillary endothelial cells (BCECs, Hypothalamus)

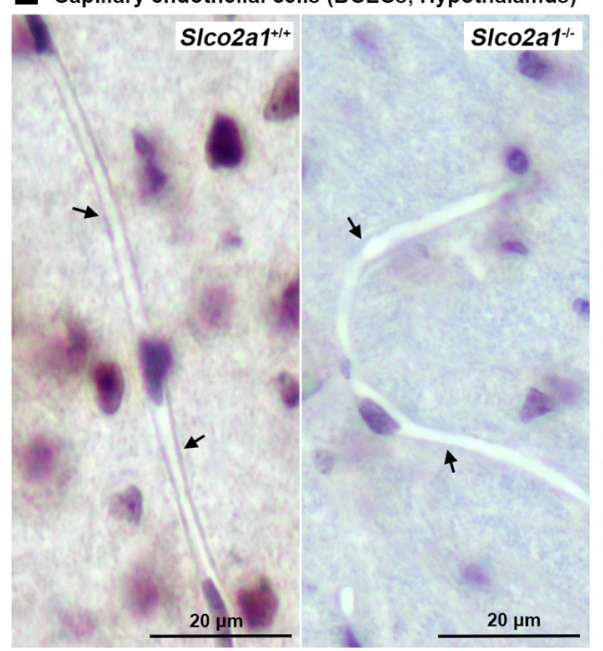

F Blood vessels (Hypothalamus) Slco2a $1^{+++}$

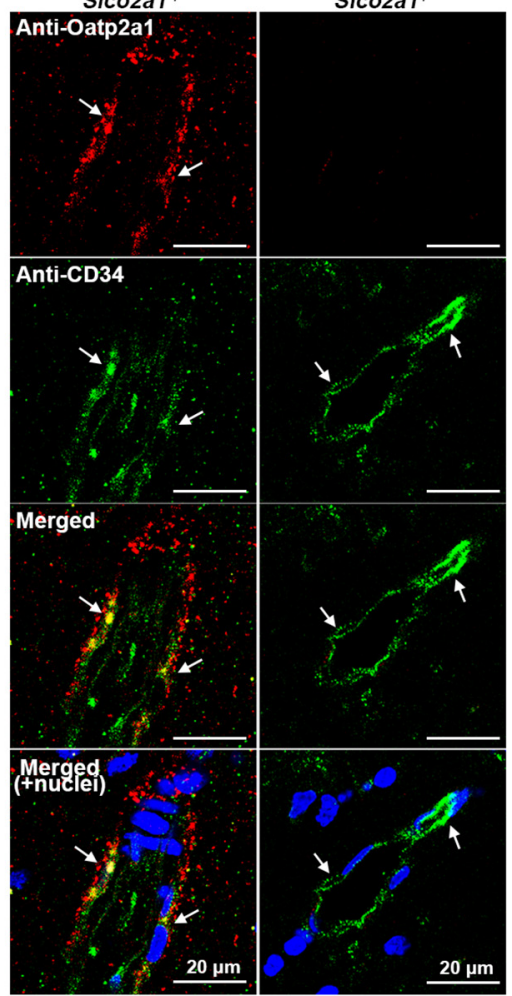

G Blood vessels (Hypothalamus)

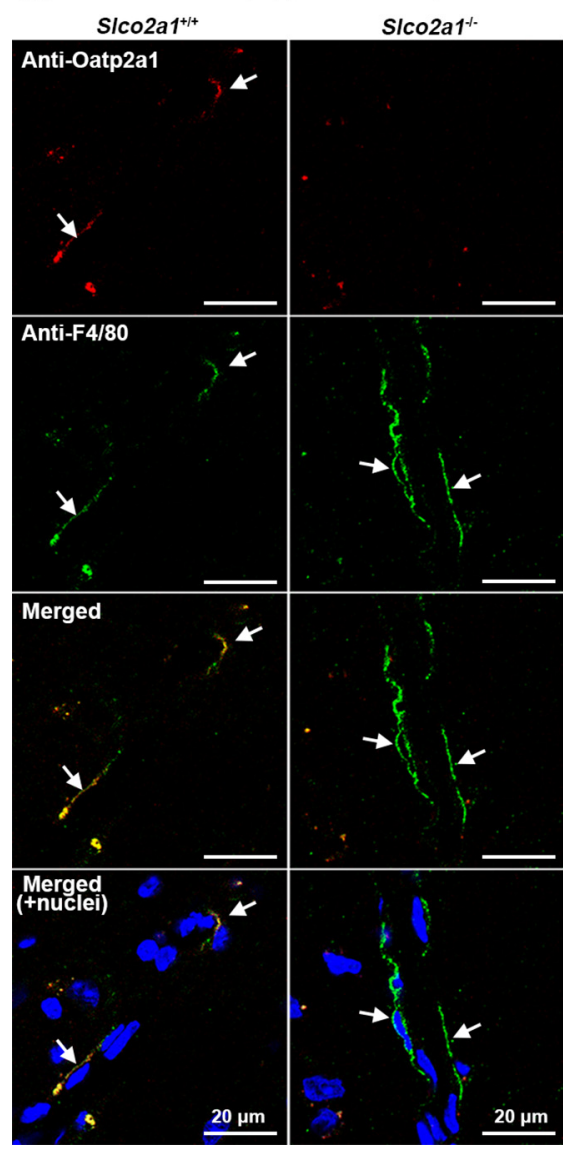

H Brain parenchyma (Hypothalamus)

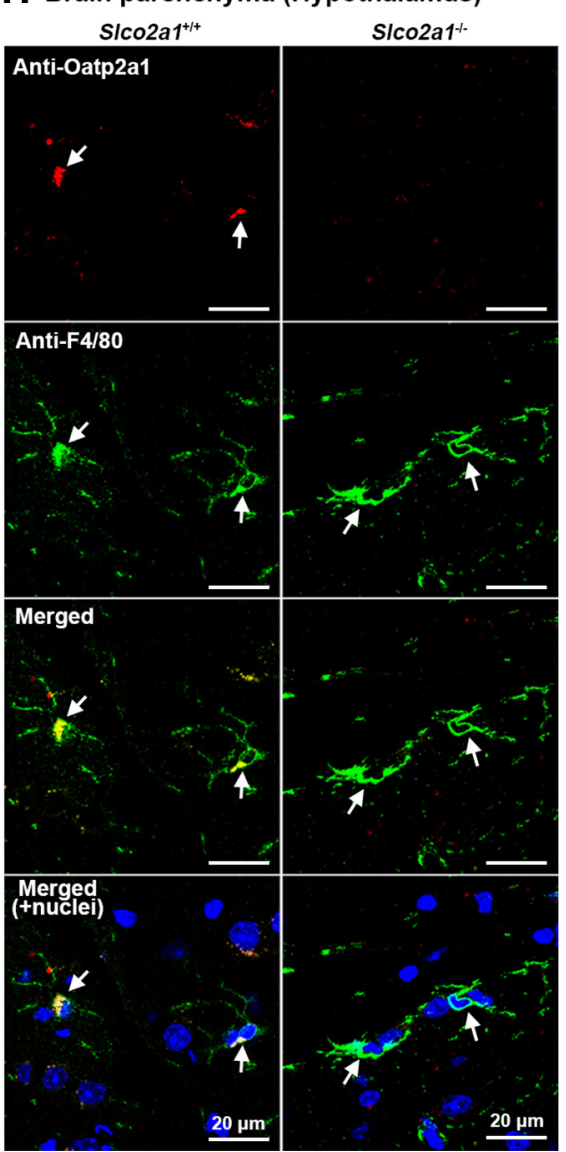

I Blood vessels (Hypothalamus)

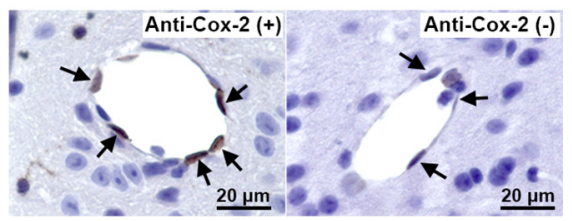

J Brain parenchyma (Hypothalamus)
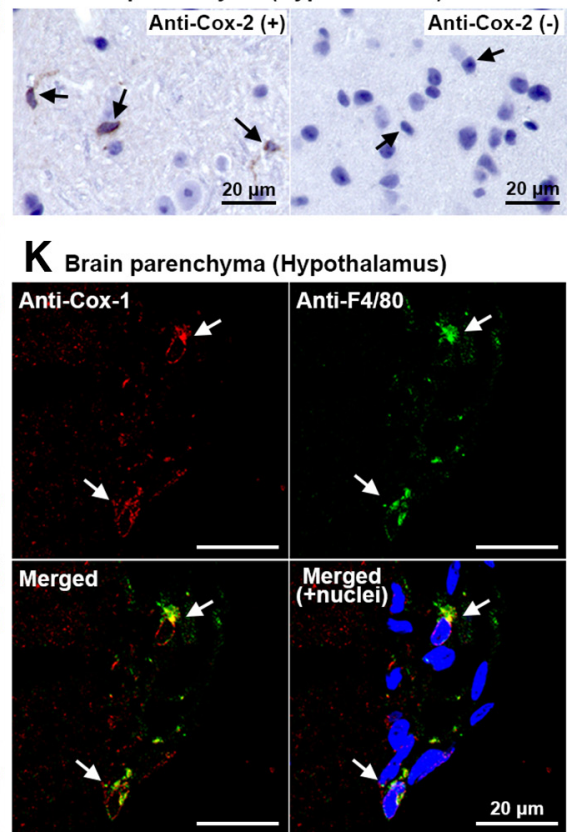

Figure 4. Localization of 0atp2a1 and Cox in mouse brain. $\boldsymbol{A}-\boldsymbol{E}$, Immunostaining of 0atp2a1 in the CP region $(\boldsymbol{A})$, parenchyma of the hypothalamus $(\boldsymbol{B}, \boldsymbol{C})$, cerebral cortex $(\boldsymbol{D})$, and capillary endothelial cells of the hypothalamus $(\boldsymbol{E})$ in paraffin-embedded sections of Slco2a ${ }^{+/+}$and Slco2a ${ }^{-/-}$mice. $\boldsymbol{F}-\boldsymbol{H}$, Dual immunostaining of 0atp2a1 and CD34 (blood vessels; $\boldsymbol{F}$ ) or F4/80 [blood vessels $(\boldsymbol{G})$ and parenchymal cells $(\boldsymbol{H})]$ in frozen brain sections of Slco2a ${ }^{+/+}$and Slco2a ${ }^{-1-}$ mice. $\boldsymbol{I}, \boldsymbol{J}$, Cox-2 immunostaining in paraffin-embedded sections (Figure legend continues.) 


\section{A Abundance of SIco2a1 allele}

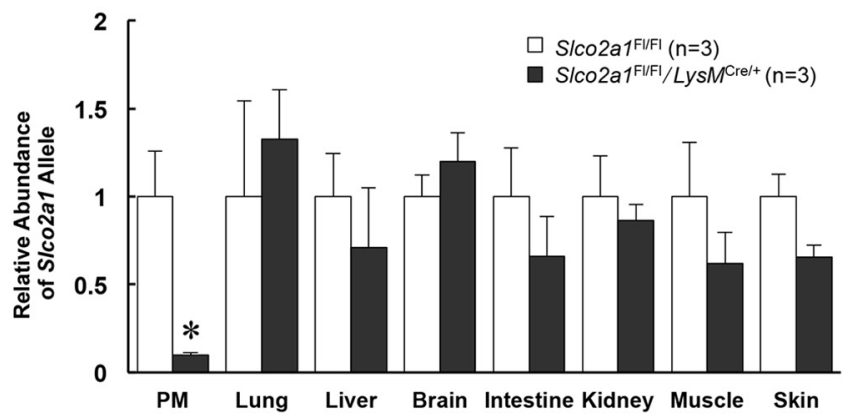

B mRNA expression of SIco2a1

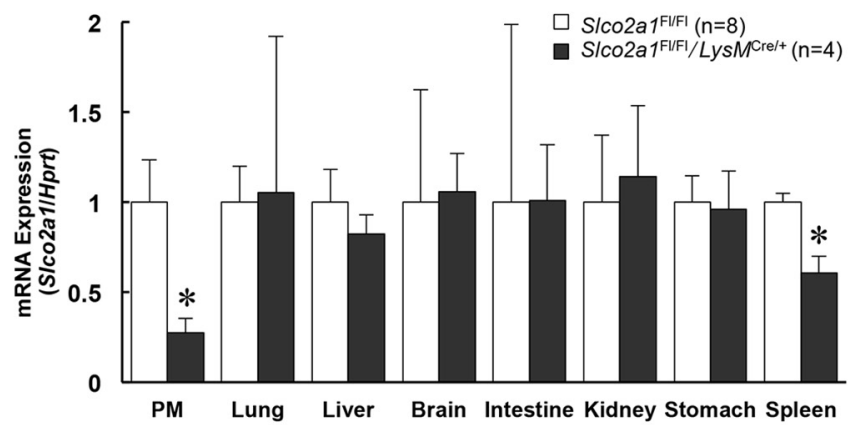

\section{Brain parenchyma (Hypothalamus)}

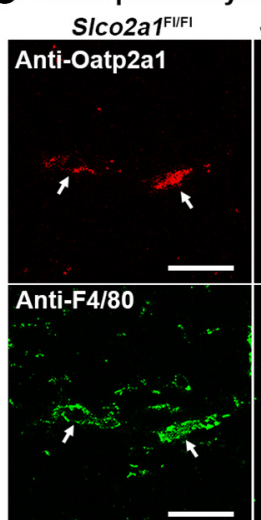

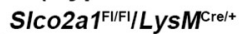
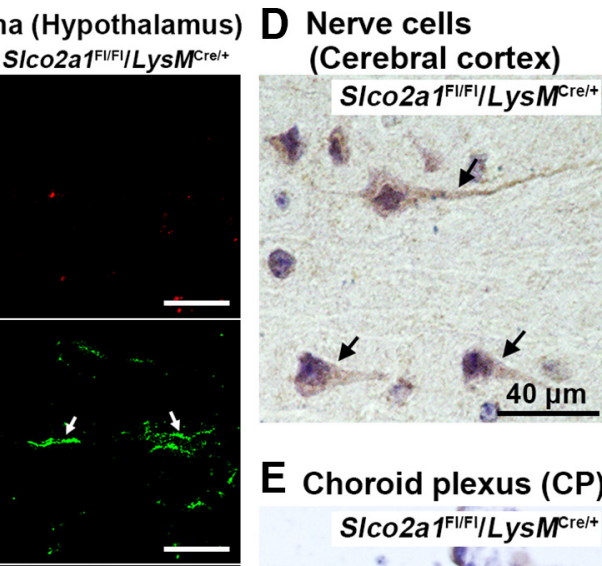

E Choroid plexus (CP)

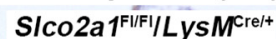
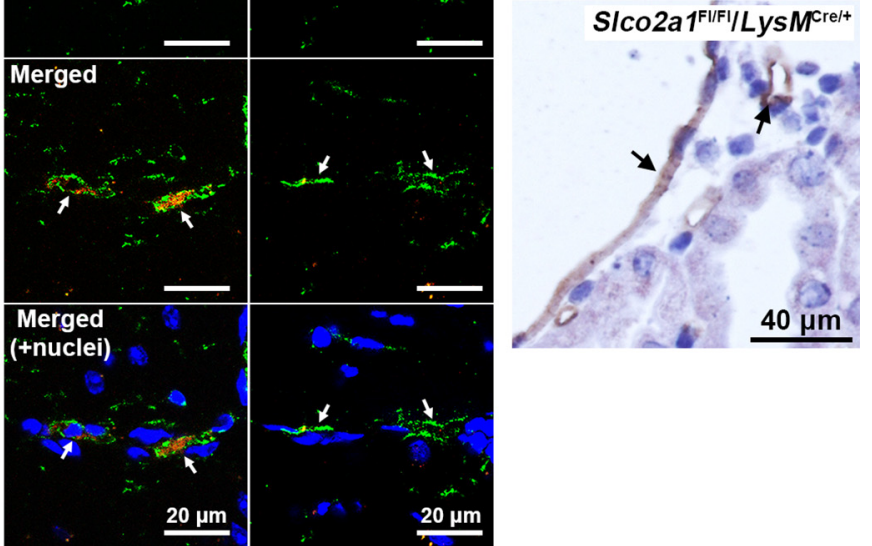

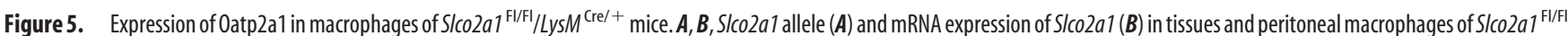

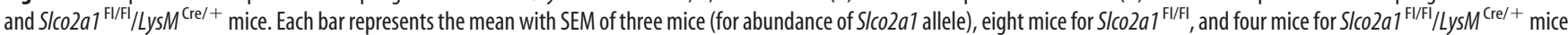
(for mRNA expression). The asterisk indicates statistically significant differences ( $p<0.05$ ) by Student's $t$ test. C, Dual immunostaining of 0 atp2a1 and F4/80 in frozen brain sections of S/co2a 1 FI/FI

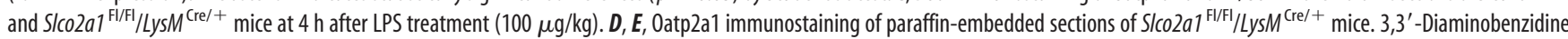
staining of nerve cells $(\boldsymbol{D})$ and the $(P$ region $(\boldsymbol{E})$. Nuclei were counterstained with Hoechst33342 (C) or hematoxylin $(\boldsymbol{D}, \boldsymbol{E})$. Arrows indicate expression of the indicated protein. The illustrations are representative of the results of at least three individual mice in each group.

cantly decreased in peritoneal macrophages $(p=0.006)$ and spleen $(p=0.036)$ of Slco $2 a 1^{\mathrm{Fl} / \mathrm{Fl}} / L y s M^{\mathrm{Cre} /+}$ mice compared with Slco $2 a 1^{\mathrm{Fl} / \mathrm{Fl}}$ mice (Fig. $5 B$ ). Reduced Oatp2al protein expression was confirmed in F4/80-positive cells by means of fluorescence immunohistochemistry (Fig. $5 C$ ). The ratio of Oatp2a1-positive cells to F4/80-positive cells was significantly reduced in brain sections of Slco $2 a 1^{\mathrm{Fl} / \mathrm{Fl}} / L y s M^{\mathrm{Cre} /+}$ mice $(0.29 \pm 0.04)$ compared with Slco $2 a 1^{\mathrm{Fl} / \mathrm{Fl}}$ mice $(0.71 \pm 0.06, p<0.001)$. In contrast, Oatp2a1 staining was observed in axial fibers of nerve cells and in the $\mathrm{CP}$ of Slco2a $1^{\mathrm{Fl} / \mathrm{Fl}} /$ Lys $^{\mathrm{Cre} /+}$ mice (Fig. $5 D, E$ ). Therefore, the effect of Slco2a1 deficiency in F4/80-positive cells on febrile response was further examined in LPS-injected Slco2a $1^{\mathrm{Fl} / \mathrm{Fl}}$ LysM $M^{\mathrm{Cre} /+}$ mice.

The time courses of Tc were similar in PS-injected Slco2a ${ }^{\mathrm{Fl} / \mathrm{Fl}}$ (control group) and Slco2al $1^{\mathrm{Fl} / \mathrm{Fl}} / \mathrm{LysM}^{\mathrm{Cre} /+}$ mice, and no significant change in Tc was observed during the test period. On the other hand, Tc in Slco2a $1^{\mathrm{Fl} / \mathrm{Fl}}$ mice was elevated at $2 \mathrm{~h}$ and reached a plateau at $5 \mathrm{~h}$ after LPS treatment $\left(35.9^{\circ} \mathrm{C}\right.$; Fig. $\left.6 \mathrm{~A}\right)$, which is similar to the result in Slco2al $1^{+/+}$mice (Fig. 1A). In Slco2a $1^{\mathrm{Fl} / \mathrm{Fl} /}$

$\leftarrow$

(Figure legend continued.) of the hypothalamus of S/co2a ${ }^{+/+}$mice showing blood vessels $(I)$ and brain parenchymal cells $(J) . K$, Dual immunostaining of Cox- 1 and anti-F4/80 in frozen sections of brain parenchyma. Nuclei were counterstained with hematoxylin $(\boldsymbol{A}-\boldsymbol{E}, \boldsymbol{I}, \boldsymbol{I})$ or Hoechst33342 $(\boldsymbol{F}-\boldsymbol{H}, \boldsymbol{K})$. Sections were prepared from at least three individual SICO2a ${ }^{+/+}$and Slco2a ${ }^{-1-}$ mice at $4 \mathrm{~h}$ after LPS treatment $(100 \mu \mathrm{g} / \mathrm{kg})$. Arrows indicate expression of the indicated protein.
Lys $M^{\mathrm{Cre} /+}$ mice, Tc was increased at $2 \mathrm{~h}$ but did not reach the level of Slco2a1 ${ }^{\mathrm{Fl} / \mathrm{Fl}}$ mice. The Tc of Slco2a1 ${ }^{\mathrm{Fl} / \mathrm{Fl}} /$ LysM $^{\mathrm{Cre} /+}$ mice was significantly lower than that of Slco $2 a 1^{\mathrm{Fl} / \mathrm{Fl}}$ at $6 \mathrm{~h}(p=$ $0.0044), 7 \mathrm{~h}(p=0.010)$, and $9 \mathrm{~h}(p=0.048)$ after LPS treatment (Fig. 6A). We further examined $C_{\text {isf }}$ of Slco2a $1^{\mathrm{Fl} / \mathrm{Fl}}\left(C_{\mathrm{isf,Fl}}\right)$ and Slco $2 a 1^{\mathrm{Fl} / \mathrm{Fl}} /$ LysM $^{\mathrm{Cre} /+}\left(C_{\mathrm{isf}, \mathrm{Fl} / \mathrm{LysM}}\right)$ mice using a microdialysis technique. $C_{\mathrm{isf}, \mathrm{Fl}}$ and $C_{\mathrm{isf}, \mathrm{Fl} / \mathrm{LysM}}$ peaked at $2 \mathrm{~h}$ after LPS injection, reaching 1122 and $512 \mathrm{pg} / \mathrm{ml}$, respectively. $C_{\text {isf,Fl/LysM }}$ was significantly lower than $C_{\text {isf,Fl }}$ throughout the test period ( $p<0.05$; Fig. $6 B)$. No significant difference was observed in Cox-2 $(p=0.783)$, Cox-1 $(p=0.319)$, or 15-Pgdh $(p=0.340)$ protein expression, or in Ptges $(p=0.437)$ or Ptger3 $(p=0.540)$ mRNA expression, between Slco $2 a 1^{\mathrm{Fl} / \mathrm{Fl}}$ and Slco $2 a 1^{\mathrm{Fl} / \mathrm{Fl}} / L y s M^{\mathrm{Cre} /+}$ mice (Fig. $6 C-G)$.

\section{Serum concentration of TNF- $\alpha$}

Since TNF- $\alpha$ is a major pyrogenic cytokine, we measured its serum level in LPS (100 $\mu \mathrm{g} / \mathrm{kg})$-treated Slco2al-global knock-out mice. LPS increased the serum concentration of TNF- $\alpha$ in all groups, but the concentration in Slco2al ${ }^{-1-}$ mice $(652 \mathrm{pg} / \mathrm{ml})$ was significantly lower than that in Slco2a $1^{+/+}$mice $(1084 \mathrm{pg} / \mathrm{ml}$, $p=0.011$; Fig. $7 A$ ). Similar results were obtained for serum TNF- $\alpha$ in Slco $2 a 1^{\mathrm{Fl} / \mathrm{Fl}}$ and Slco $2 a 1^{\mathrm{Fl} / \mathrm{Fl}} /$ Lys $M^{\mathrm{Cre} /+}$ mice $(675$ $\mathrm{pg} / \mathrm{ml}$ vs $473 \mathrm{pg} / \mathrm{ml}, p=0.048$; Fig. $7 B$ ), suggesting that Oatp2a1 expressed in macrophages is associated with the release of TNF- $\alpha$ from activated inflammatory cells. 

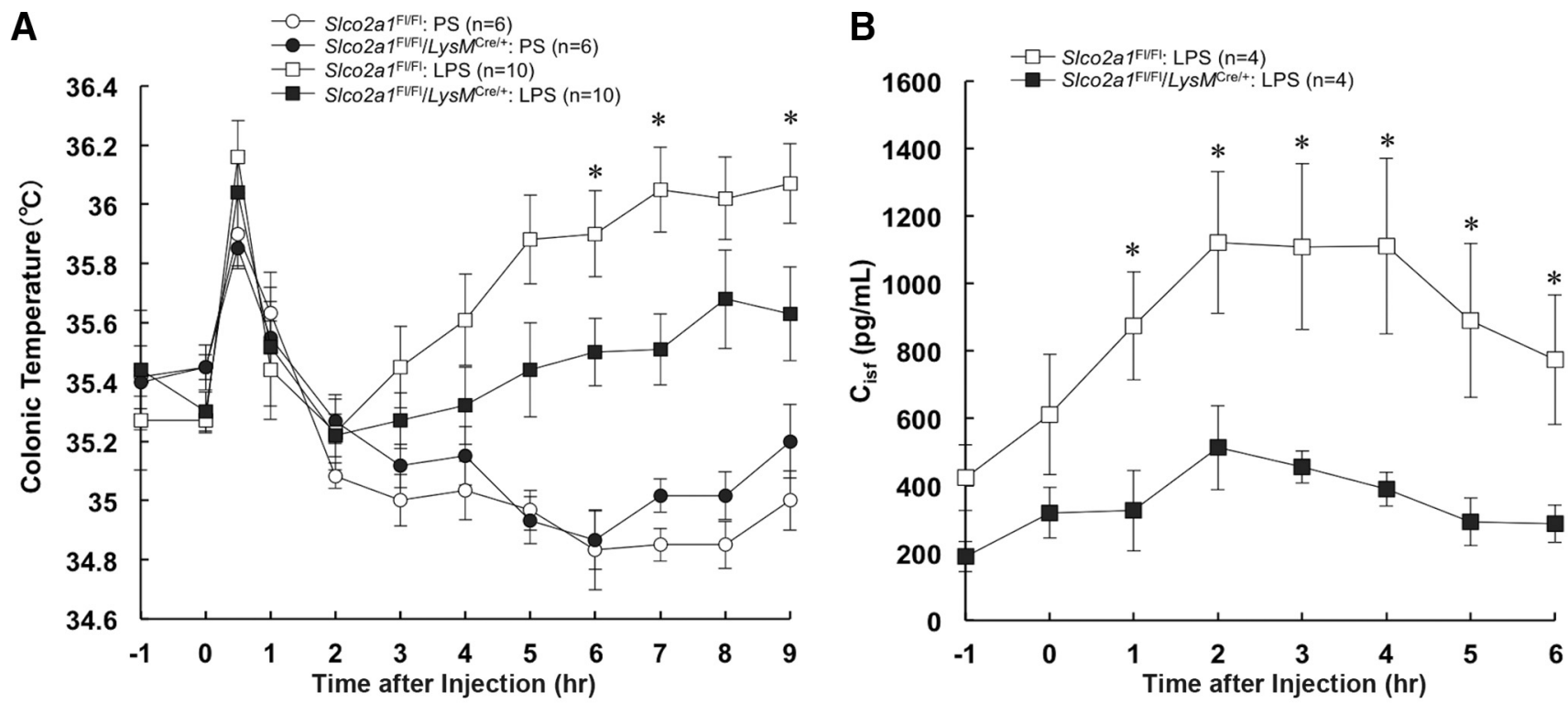

\section{Cox-2/Ptgs2}

\section{Cox-1/Ptgs1}

\section{E 15-Pgdh/Hpgd}

F Ptges (mPges-1)

G Ptger3 (Ep3)
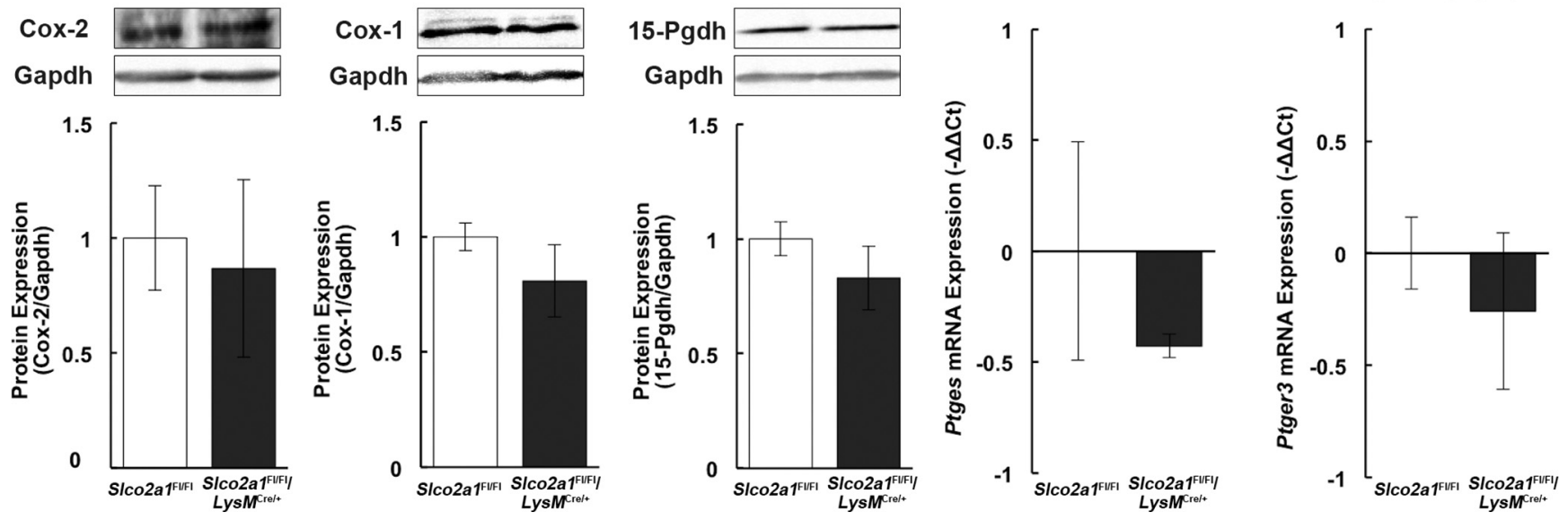

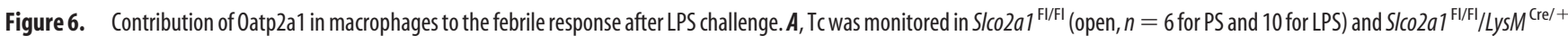

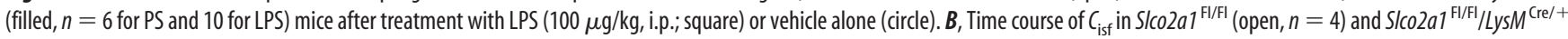
(filled, $n=4$ ) mice treated with LPS (100 $\mu \mathrm{g} / \mathrm{kg}$, i.p.). C $-\mathbf{G}$, Cox-2, Cox-1, and 15-Pgdh expression was evaluated by Western blotting ( $\boldsymbol{C}-\boldsymbol{E})$ and $\mathrm{mRNA}$ expression of Ptges and Ptger 3 was evaluated

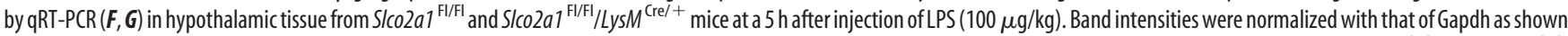
by bar graphs at the bottom ( $n=3$ for each group). Each bar represents the mean $\pm \mathrm{SEM}$. The asterisk indicates statistically significant differences $(p<0.05)$ from S/co2a ${ }^{\mathrm{F} / \mathrm{Fl}}$ and S/co2a ${ }^{\mathrm{F} / \mathrm{Fl} /}$ Lys $M^{\text {Cre/+ }}$ mice by Student's $t$ test.

\section{Discussion}

$\mathrm{PGE}_{2}$ is a major chemical mediator of the febrile response, and membrane transporters are thought to be involved in regulating its concentration in the hypothalamus, which plays a key role in regulating body temperature. However, the details remain unclear. Therefore, in the present study, we examined the role of a major prostaglandin transporter, OATP2A1/SLCO2A1, in the febrile response by using global and monocyte-/macrophagespecific Slco2a1-knock-out mice. Our findings indicate that OATP2A1 serves to maintain an increased interstitial $\mathrm{PGE}_{2}$ concentration in the hypothalamus during the febrile response.

\section{Impact of OATP2A1 on $\mathrm{PGE}_{2}$ disposition} and thermoregulation

The LPS-induced febrile response was attenuated in Slco2a1 ${ }^{-1-}$ mice (Fig. 1A). In accordance with this finding, the OATP2A1 inhibitor suramin attenuated the LPS-induced increase of Tc in rats (Fig. $1 B$ ). It has been shown that $C_{\text {csf }}$ is positively associated with $\mathrm{Tc}$, and therefore we assessed $C_{\mathrm{csf}}$ in these mice. As shown in Figure $3 A$, the time course of $C_{\text {csf.WT }}$ was consistent with changes in LPS-induced Tc in Slco2a1 ${ }^{+/+}$mice. $C_{\text {csf,Ko }}$ rose as quickly as $C_{\mathrm{csf}, \mathrm{WT}}$ but then surprisingly remained high throughout the test period. Since Oatp2al is expressed in the CP (Fig. 4A), this result presumably reflects Oatp2a1-mediated $\mathrm{PGE}_{2}$ uptake at the apical side of CP (Tachikawa et al., 2012). Namely, high $C_{\mathrm{csf}, \mathrm{KO}}$ could be attributed to reduced clearance of $\mathrm{PGE}_{2}$ from the CSF. However, the negligible change of Tc in Slco2a1 ${ }^{-1-}$ mice cannot be explained by this observation. This led us to evaluate the kinetics of $C_{\text {isf }}$ in free-moving mice by means of a microdialysis technique. $C_{\text {isf }}$ ranged from 200 to $1200 \mathrm{pg} / \mathrm{ml}$ (Figs. $3 B, 6 B$ ), which is similar to the reported ranges of $\mathrm{PGE}_{2}$ concentration in brain ISF of guinea pigs (20-1200 pg/ml; Sehic et al., 1996) and rabbits (200$3500 \mathrm{pg} / \mathrm{ml}$; Chang et al., 2013) treated with LPS ( $2 \mu \mathrm{g} / \mathrm{kg}$, i.v. $)$. These observations suggest the surgical procedure may not have 
A

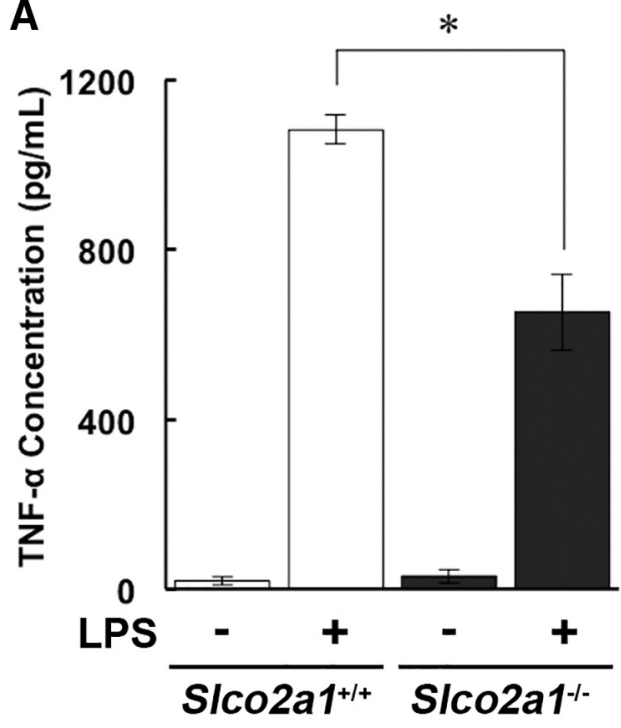

B

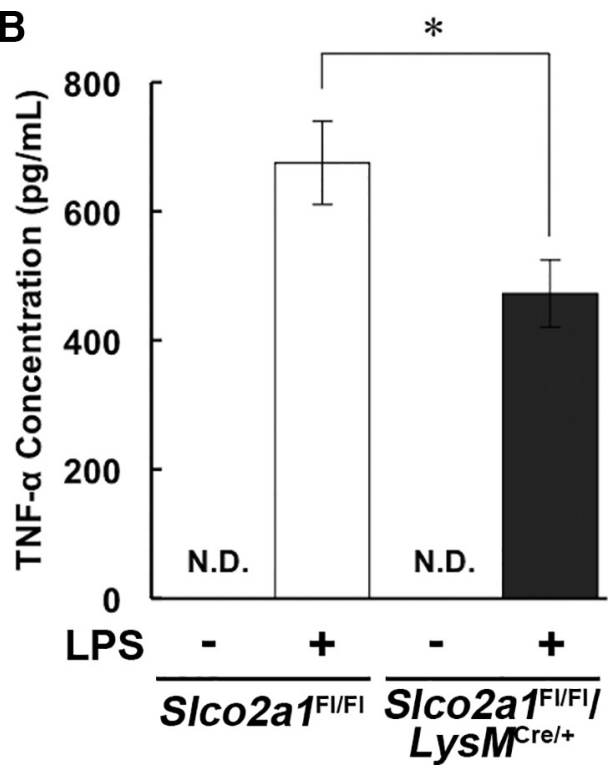

Figure 7. Effect of global and monocyte-/macrophage-specific S/co2a1 deficiency on serum levels of TNF- $\alpha$. $\boldsymbol{A}, \boldsymbol{B}$, Serum levels of TNF- $\alpha$ of global ( $\boldsymbol{A})$ and monocyte-/macrophage-specific ( $\boldsymbol{B})$ Slco2a1-knock-out mice. Animals were treated with LPS (100 $\mu \mathrm{g} / \mathrm{kg}$, i.p.) or vehicle only, and serum was collected $2 \mathrm{~h}$ later. Four S/c02a ${ }^{+/+}$or S/co2a $1^{-/-}(\boldsymbol{A})$ and 10 S/co2a ${ }^{\mathrm{Fl} / \mathrm{Fl}}$ or Slco2a ${ }^{\mathrm{Fl} / \mathrm{Fl} /} / \mathrm{LysM}^{\mathrm{Cre} /+}(\boldsymbol{B})$ mice were used. Each result represents the mean \pm SEM. N.D., Not detected. The asterisk indicates statistically significant differences $(p<0.05)$ by Student's $t$ test.

had a marked effect on $C_{\text {isf }}$ levels in our experiment. In contrast to $C_{\text {csf,KO}}, C_{\text {isf,Ko }}$ did not rise and remained at the basal level. Because ISF-CSF communication at the inner ventricle surface is supposed to occur freely, concentrations of solutes in brain ISF are generally equivalent to those in CSF (Lei et al., 2017). This was not the case in Slco2a1 ${ }^{-1-}$ mice $\left(C_{\text {isf }}, 380 \mathrm{pg} / \mathrm{ml} ; C_{\mathrm{csf}}, 1182 \mathrm{pg} /\right.$ $\mathrm{ml}$ ). This suggests that independent mechanisms operate in the regulation of $\mathrm{PGE}_{2}$ concentration in the two regions.

Moreover, $C_{\text {hyp }}$ was estimated as $\sim 12,000 \mathrm{pg} / \mathrm{ml}$ in mice before LPS injection, and $C_{\text {isf,max }}$ was, at most, $7 \%$ of this value in Slco2a $1^{+/+}$mice (Fig. $3 B, C$ ). The high tissue concentration of $\mathrm{PGE}_{2}$ could be attributed to a high tissue-bound fraction, although we could not determine the bound fraction in this study. Brain interstitial space corresponds to a few percent of the volume of brain parenchyma, and intracellular $\mathrm{PGE}_{2}$ concentration is not necessarily associated with $C_{\text {isf }}$. It was not established whether newly synthesized or pre-existing $\mathrm{PGE}_{2}$ mediates the febrile response. Considering the antipyretic effect of COX inhibitors, it seems likely that newly synthesized $\mathrm{PGE}_{2}$ is involved; however, intracerebrally injected suramin, which does not inhibit $\mathrm{PGE}_{2}$ production (Kamo et al., 2017), partially attenuated the rise of Tc in rats. Also, Slco2a $1^{+/+}$and Slco2a1 ${ }^{-/-}$mice showed similar ability to respond to inflammation (Fig. 2). Therefore, we hypothesized that $C_{\text {isf }}$ in the hypothalamus is regulated by OATP2A1-mediated transport, and we next examined which cells secrete $\mathrm{PGE}_{2}$.

\section{Contribution of OATP2A1 in macrophages to development of the febrile response}

Oatp2al was detected in many cells, including microglia, astrocytes, nerve cells, and BCECs (Fig. 4), in agreement with previous work (Kis et al., 2006; Choi et al., 2008). Astrocytes (Mishra et al., 2016) and nerve cells (Lacroix et al., 2015) in the brain constitutively synthesize $\mathrm{PGE}_{2}$. Moreover, Cox-2 is expressed not only in blood vessels but also in brain parenchyma (Fig. $4 I, J$ ). Perivascular macrophages and microglia secrete $\mathrm{PGE}_{2}$ under inflammatory conditions (Elmquist et al., 1997; Schiltz and Sawchenko, 2002). Previous studies, including ours, suggest that OATP2A1 is dominantly expressed in cytoplasm of astrocytes and macrophages (Gordon et al., 2008; Shimada et al., 2015). We recently showed that OATP2A1 facilitates $\mathrm{PGE}_{2}$ exocytosis from murine macrophages (Shimada et al., 2015). Moreover, the LPS-induced febrile response was significantly attenuated by monocyte-/ macrophage-specific Slco2al deficiency (Fig. 6A), in association with decreased $C_{\text {isf }}$ (Fig. 6B). Accordingly, these results suggest that OATP2A1 is involved in $\mathrm{PGE}_{2}$ secretion from macrophages during the febrile response. Cox-2 is not a determinant of LPSinduced fever generation in LysM-positive cells (Nilsson et al., 2017). However, Cox-1 was expressed in F4/80-positive cells (Fig. $4 K)$, in agreement with the previous report of Cox-1 expression in microglia and perivascular cells (García-Bueno et al., 2009). There is also evidence of the involvement of microglial COX-1 in immune challenge-induced neuroinflammation in various models (Candelario-Jalil et al., 2007; García-Bueno et al., 2009). Therefore, we cannot rule out the possibility that $\mathrm{PGE}_{2}$ produced via Cox-1 and secreted from microglia and perivascular cells via OATP2A1 is essential for the febrile response. Another possibility is that the increase of $C_{\text {isf }}$ under inflammatory conditions is attributable to altered OATP2A1 activity, since LPS-induced transcriptional upregulation of rat Oatp2a1 has been reported (Hosotani et al., 2015). Further studies are needed to establish the underlying mechanism.

Tc and $C_{\text {isf }}$ were partially decreased in Slco2a $1^{\mathrm{Fl} / \mathrm{Fl}} / L y s M^{\mathrm{Cre} /+}$ mice (Fig. $6 A, B$ ); therefore, Oatp2a1 in cells other than macrophages may also contribute to the febrile response. As the blood $\mathrm{PGE}_{2}$ concentration rises concomitantly with body temperature, the entry of peripherally synthesized $\mathrm{PGE}_{2}$ is suggested to trigger the response (Steiner et al., 2006; Wilhelms et al., 2014). Here, we found that Oatp2al is expressed in BCECs in vivo (Fig. 4E); this result is consistent with its expression at the apical membranes of primary-cultured rat BCECs (Kis et al., 2006). In contrast to the remarkable elevation of $C_{\mathrm{p}}$ in Slco2a1 ${ }^{-1-}$ mice ( $0.60 \mathrm{nM}$; Fig. $3 E$ ), basal $C_{\text {isf }}$ was not affected (Fig. $3 B$ ), although OATP2A1 is unlikely to be saturated ( $K_{\mathrm{m}}$ for $\mathrm{PGE}_{2}$ is about $100 \mathrm{nM}$ ); therefore, our data suggest a role of OATP2A1 in $\mathrm{PGE}_{2}$ uptake by BCECs, as in endothelial cells of other tissues (Nakanishi et al., 2017; Na- 
kanishi and Tamai, 2018). Thus, OATP2A1 may contribute to $\mathrm{PGE}_{2}$ transport into the brain.

OATP2A1 is a $\mathrm{PGE}_{2} /$ lactate exchanger (Chan et al., 2002). Considering that the physiological lactate concentration in the brain is higher than that in plasma of mammals (Abi-Saab et al., 2002), it is reasonable to suppose that OATP2A1 facilitates $\mathrm{PGE}_{2}$ efflux from endothelial cells into the brain interstitial space. BCECs are accepted to be a major source of $\mathrm{PGE}_{2}$ during the febrile response (Yamagata et al., 2001; Engström et al., 2012); however, the mechanism of $\mathrm{PGE}_{2}$ release from these cells has been little explored. We speculate that Oatp2al contributes to the febrile response by participating in $\mathrm{PGE}_{2}$ transport across and/or secretion from BCECs in exchange for extracellular lactate. Furthermore, OATP2A1 may serve to maintain an increased level of $C_{\text {isf }}$ during the febrile response.

\section{Impact of Slco2a1 deficiency on serum TNF- $\alpha$ level and its effect on the febrile response}

Serum TNF- $\alpha$ was also significantly increased by LPS in all test animals, but the increase was significantly smaller in Slco2a ${ }^{-1-}$ and Slco2al ${ }^{\mathrm{F} / \mathrm{Fl}} / L y s M^{\mathrm{Cre} /+}$ mice than in their respective counterparts (Fig. $7 A, B$ ). TNF- $\alpha$ induces protein expression of Cox-2 in the brain during the febrile response (Cao et al., 1998); nevertheless, our present data suggest that Slco2a1 deficiency did not affect the Cox-2 protein level in the hypothalamus after LPS injection (Figs. 2C, 6C). This is also supported by the observation that $\mathrm{PGE}_{2}$ concentration in the hypothalamus was similar in Slco2al ${ }^{+/+}$and Slco2a1 ${ }^{-1-}$ mice at $5 \mathrm{~h}$ after LPS treatment (Fig. $3 C$ ). Furthermore, it was reported that LPS-induced fever was not affected in rats given injections of a nonsteroidal anti-inflammatory drug, nimesulide, despite a substantial decrease in serum TNF- $\alpha$ (from 3237 to $564 \mathrm{pg} / \mathrm{ml}$; Dogan et al., 2002). Therefore, the difference in TNF- $\alpha$ levels may have had little impact on the LPS-induced increase in Tc in our experiment.

In conclusion, our findings indicate that OATP2A1 mediates $\mathrm{PGE}_{2}$ secretion from F4/80-positive glial cells in the hypothalamus, as well as $\mathrm{PGE}_{2}$ transport across the $\mathrm{BBB}$ and secretion from BCECs. Thus, OATP2A1 appears to be a key determinant of the $\mathrm{PGE}_{2}$ concentration in hypothalamus interstitial fluid, which is the proximal mediator of the LPS-induced febrile response. We believe these findings on the multiple roles of OATP2A1 contribute to our understanding of the mechanisms of inflammatory response in the brain and may provide a clue to develop new therapeutic strategies for treating refractory neuroinflammatory diseases.

\section{References}

Abi-Saab WM, Maggs DG, Jones T, Jacob R, Srihari V, Thompson J, Kerr D, Leone P, Krystal JH, Spencer DD, During MJ, Sherwin RS (2002) Striking differences in glucose and lactate levels between brain extracellular fluid and plasma in conscious human subjects: effects of hyperglycemia and hypoglycemia. J Cereb Blood Flow Metab 22:271-279. CrossRef Medline

Akanuma S, Uchida Y, Ohtsuki S, Tachikawa M, Terasaki T, Hosoya K (2011) Attenuation of prostaglandin E2 elimination across the mouse blood-brain barrier in lipopolysaccharide-induced inflammation and additive inhibitory effect of cefmetazole. Fluids Barriers CNS 8:24. CrossRef Medline

Alix E, Schmitt C, Strazielle N, Ghersi-Egea JF (2008) Prostaglandin E2 metabolism in rat brain: role of the blood-brain interfaces. Cerebrospinal Fluid Res 5:5. CrossRef Medline

Candelario-Jalil E, de Oliveira AC, Gräf S, Bhatia HS, Hüll M, Muñoz E,Fiebich BL (2007) Resveratrol potently reduces prostaglandin E2 production and free radical formation in lipopolysaccharide-activated primary rat microglia. J Neuroinflammation 4:25. CrossRef Medline
Cao C, Matsumura K, Yamagata K, Watanabe Y (1995) Induction by lipopolysaccharide of cyclooxygenase- 2 mRNA in rat brain; its possible role in the febrile response. Brain Res 697:187-196. CrossRef Medline

Cao C, Matsumura K, Yamagata K, Watanabe Y (1998) Cyclooxygenase-2 is induced in brain blood vessels during fever evoked by peripheral or central administration of tumor necrosis factor. Brain Res Mol Brain Res 56:45-56. CrossRef Medline

Chan BS, Endo S, Kanai N, Schuster VL (2002) Identification of lactate as a driving force for prostanoid transport by prostaglandin transporter PGT. Am J Physiol Renal Physiol 282:F1097-F1102. CrossRef Medline

Chang CH, Huang WT, Kao CH, Chen SH, Lin CH (2013) Tetramethylpyrazine decreases hypothalamic glutamate, hydroxyl radicals and prostaglandin-E2 and has antipyretic effects. Inflamm Res 62:527-535. CrossRef Medline

Chang HY, Locker J, Lu R, Schuster VL (2010) Failure of postnatal ductus arteriosus closure in prostaglandin transporter-deficient mice. Circulation 121:529-536. CrossRef Medline

Choi K, Zhuang H, Crain B, Doré S (2008) Expression and localization of prostaglandin transporter in Alzheimer disease brains and age-matched controls. J Neuroimmunol 195:81-87. CrossRef Medline

Dogan MD, Ataoglu H, Akarsu ES (2002) Nimesulide and diclofenac inhibit lipopolysaccharide-induced hypothermia and tumour necrosis factoralpha elevation in rats. Fundam Clin Pharmacol 16:303-309. CrossRef Medline

Elmquist JK, Breder CD, Sherin JE, Scammell TE, Hickey WF, Dewitt D, Saper CB (1997) Intravenous lipopolysaccharide induces cyclooxygenase 2-like immunoreactivity in rat brain perivascular microglia and meningeal macrophages. J Comp Neurol 381:119-129. CrossRef Medline

Engblom D, Saha S, Engström L, Westman M, Audoly LP, Jakobsson PJ, Blomqvist A (2003) Microsomal prostaglandin E synthase-1 is the central switch during immune-induced pyresis. Nat Neurosci 6:1137-1138. CrossRef Medline

EngströmL, Ruud J, Eskilsson A, Larsson A, Mackerlova L, Kugelberg U, Qian H, Vasilache AM, Larsson P, Engblom D, Sigvardsson M, JönssonJI, Blomqvist A (2012) Lipopolysaccharide-induced fever depends on prostaglandin E2 production specifically in brain endothelial cells. Endocrinology 153:4849-4861. CrossRef Medline

García-Bueno B, Serrats J, Sawchenko PE (2009) Cerebrovascular cyclooxygenase-1 expression, regulation, and role in hypothalamic-pituitary-adrenal axis activation by inflammatory stimuli. J Neurosci 29:12970-12981. CrossRef Medline

Glowinski J, Iversen LL (1966) Regional studies of catecholamines in the rat brain. I. The disposition of $[3 \mathrm{H}]$ norepinephrine, $[3 \mathrm{H}]$ dopamine and $[3 \mathrm{H}]$ dopa in various regions of the brain. J Neurochem 13:655-669. CrossRef Medline

Gordon GR, Choi HB, Rungta RL, Ellis-Davies GC, MacVicar BA (2008) Brain metabolism dictates the polarity of astrocyte control over arterioles. Nature 456:745-749. CrossRef Medline

Gose T, Nakanishi T, Kamo S, Shimada H, Otake K, Tamai I (2016) Prostaglandin transporter (OATP2A1/SLCO2A1) contributes to local disposition of eicosapentaenoic acid-derived PGE. Prostaglandins Other Lipid Mediat 122:10-17. CrossRef Medline

Hosotani R, Inoue W, Takemiya T, Yamagata K, Kobayashi S, Matsumura K (2015) Prostaglandin transporter in the rat brain: its localization and induction by lipopolysaccharide. Temperature (Austin) 2:425-434. CrossRef Medline

Ivanov AI, Romanovsky AA (2004) Prostaglandin E2 as a mediator of fever: synthesis and catabolism. Front Biosci 9:1977-1993. CrossRef Medline

Ivanov AI, Scheck AC, Romanovsky AA (2003) Expression of genes controlling transport and catabolism of prostaglandin E2 in lipopolysaccharide fever. Am J Physiol Regul Integr Comp Physiol 284:R698-R706. CrossRef Medline

Kamo S, Nakanishi T, Aotani R, Nakamura Y, Gose T, Tamai I (2017) Impact of FDA-approved drugs on the prostaglandin transporter OATP2A1/ SLCO2A1. J Pharm Sci 106:2483-2490. CrossRef Medline

Kanai N, Lu R, Satriano JA, Bao Y, Wolkoff AW, Schuster VL (1995) Identification and characterization of a prostaglandin transporter. Science 268:866-869. CrossRef Medline

Kasai T, Nakanishi T, Ohno Y, Shimada H, Nakamura Y, Arakawa H, Tamai I (2016) Role of OATP2A1 in PGE2 secretion from human colorectal cancer cells via exocytosis in response to oxidative stress. Exp Cell Res 341:123-131. CrossRef Medline 
Kis B, Isse T, Snipes JA, Chen L, Yamashita H, Ueta Y, Busija DW (2006) Effects of LPS stimulation on the expression of prostaglandin carriers in the cells of the blood-brain and blood-cerebrospinal fluid barriers. J Appl Physiol 100:1392-1399. CrossRef Medline

Lacroix A, Toussay X, Anenberg E, Lecrux C, Ferreirós N, Karagiannis A, Plaisier F, Chausson P, Jarlier F, Burgess SA, Hillman EM, Tegeder I, Murphy TH, Hamel E, Cauli B (2015) COX-2-derived prostaglandin E2 produced by pyramidal neurons contributes to neurovascular coupling in the rodent cerebral cortex. J Neurosci 35:11791-11810. CrossRef Medline

Laflamme N, Lacroix S, Rivest S (1999) An essential role of interleukinlbeta in mediating NF-kappaB activity and COX-2 transcription in cells of the blood-brain barrier in response to a systemic and localized inflammation but not during endotoxemia. J Neurosci 19:10923-10930. CrossRef Medline

Lei Y, Han H, Yuan F, Javeed A, Zhao Y (2017) The brain interstitial system: anatomy, modeling, in vivo measurement, and applications. Prog Neurobiol 157:230-246. CrossRef Medline

Li S, Wang Y, Matsumura K, Ballou LR, Morham SG, Blatteis CM (1999) The febrile response to lipopolysaccharide is blocked in cyclooxygenase2(-/-), but not in cyclooxygenase-1(-/-) mice. Brain Res 825:86-94. CrossRef Medline

Mishra A, Reynolds JP, Chen Y, Gourine AV, Rusakov DA, Attwell D (2016) Astrocytes mediate neurovascular signaling to capillary pericytes but not to arterioles. Nat Neurosci 19:1619-1627. CrossRef Medline

Nakanishi T, Tamai I (2018) Roles of organic anion transporting polypeptide 2A1 (OATP2A1/SLCO2A1) in regulating the pathophysiological actions of prostaglandins. AAPS J 20:13. CrossRef Medline

Nakanishi T, Hasegawa Y, Mimura R, Wakayama T, Uetoko Y, Komori H, Akanuma S, Hosoya K, Tamai I (2015) Prostaglandin transporter (PGT/ SLCO2A1) protects the lung from bleomycin-induced fibrosis. PLoS One 10:e0123895. CrossRef Medline

Nakanishi T, Ohno Y, Aotani R, Maruyama S, Shimada H, Kamo S, Oshima H, Oshima M, Schuetz JD, Tamai I (2017) A novel role for OATP2A1/ SLCO2A1 in a murine model of colon cancer. Sci Rep 7:16567. CrossRef Medline

Nakano J, Prancan AV, Moore SE (1972) Metabolism of prostaglandin E 1 in the cerebral cortex and cerebellum of the dog and rat. Brain Res 39: 545-548. CrossRef Medline

Nilsson A, Wilhelms DB, Mirrasekhian E, Jaarola M, Blomqvist A, Engblom D (2017) Inflammation-induced anorexia and fever are elicited by distinct prostaglandin dependent mechanisms, whereas conditioned taste aversion is prostaglandin independent. Brain Behav Immun 61:236-243. CrossRef Medline

Nomura DK, Morrison BE, Blankman JL, Long JZ, Kinsey SG, Marcondes MC, Ward AM, Hahn YK, Lichtman AH, Conti B, Cravatt BF (2011) Endocannabinoid hydrolysis generates brain prostaglandins that promote neuroinflammation. Science 334:809-313. CrossRef Medline

Oka T, Oka K, Kobayashi T, Sugimoto Y, Ichikawa A, Ushikubi F, Narumiya S, Saper CB (2003) Characteristics of thermoregulatory and febrile responses in mice deficient in prostaglandin EP1 and EP3 receptors. J Physiol 551:945-954. CrossRef Medline
Paxinos G, Franklin K (2012) Paxinos and Franklin's the mouse brain in stereotaxic coordinates, Ed 4. Cambridge, MA:Academic Press.

Paxinos G, Watson C (2013) The rat brain in stereotaxic coordinates, Ed 7. Cambridge, MA:Academic Press.

Romanovsky AA, Almeida MC, Aronoff DM, Ivanov AI, Konsman JP, Steiner AA, Turek VF (2005) Fever and hypothermia in systemic inflammation: recent discoveries and revisions. Front Biosci 10:2193-2216. CrossRef Medline

Roth J, Blatteis CM (2014) Mechanisms of fever production and lysis: lessons from experimental LPS fever. Compr Physiol 4:1563-1604. Medline

Saper CB, Romanovsky AA, Scammell TE (2012) Neural circuitry engaged by prostaglandins during the sickness syndrome. Nat Neurosci 15:10881095. CrossRef Medline

Schiltz JC, Sawchenko PE (2002) Distinct brain vascular cell types manifest inducible cyclooxygenase expression as a function of the strength and nature of immune insults. J Neurosci 22:5606-5618. CrossRef Medline

Schuster VL (2015) The ins and outs of prostaglandin E2 in fever. Temperature (Austin) 2:326-327. CrossRef

Sehic E, SzékelyM, Ungar AL, Oladehin A, Blatteis CM (1996) Hypothalamic prostaglandin E2 during lipopolysaccharide-induced fever in guinea pigs. Brain Res Bull 39:391-399. CrossRef Medline

Shimada H, Nakamura Y, Nakanishi T, Tamai I (2015) OATP2A1/ SLCO2A1-mediated prostaglandin E loading into intracellular acidic compartments of macrophages contributes to exocytotic secretion. Biochem Pharmacol 98:629-638. CrossRef Medline

Shirasaka Y, Shichiri M, Kasai T, Ohno Y, Nakanishi T, Hayashi K, Nishiura A, Tamai I (2013) A role of prostaglandin transporter in regulating $\mathrm{PGE}_{2}$ release from human bronchial epithelial BEAS-2B cells in response to LPS. J Endocrinol 217:265-274. CrossRef Medline

Steiner AA, Rudaya AY, Robbins JR, Dragic AS, Langenbach R, Romanovsky AA (2005) Expanding the febrigenic role of cyclooxygenase-2 to the previously overlooked responses. Am J Physiol Regul Integr Comp Physiol 289:R1253-R1257. CrossRef Medline

Steiner AA, Ivanov AI, Serrats J, Hosokawa H, Phayre AN, Robbins JR, Roberts JL, Kobayashi S, Matsumura K, Sawchenko PE, Romanovsky AA (2006) Cellular and molecular bases of the initiation of fever. PLoS Biol 4:e284. CrossRef Medline

Tachikawa M, Tsuji K, Yokoyama R, Higuchi T, Ozeki G, Yashiki A, Akanuma S, Hayashi K, Nishiura A, Hosoya K (2012) A clearance system for prostaglandin D2, a sleep-promoting factor, in cerebrospinal fluid: role of the blood-cerebrospinal barrier transporters. J Pharmacol Exp Ther 343:608-616. CrossRef Medline

Wilhelms DB, Kirilov M, Mirrasekhian E, Eskilsson A, Kugelberg UÖ, Klar C, Ridder DA, Herschman HR, Schwaninger M, Blomqvist A, Engblom D (2014) Deletion of prostaglandin E2 synthesizing enzymes in brain endothelial cells attenuates inflammatory fever. J Neurosci 34:11684-11690. CrossRef Medline

Yamagata K, Matsumura K, Inoue W, Shiraki T, Suzuki K, Yasuda S, Sugiura H, Cao C, Watanabe Y, Kobayashi S (2001) Coexpression of microsomal-type prostaglandin $\mathrm{E}$ synthase with cyclooxygenase- 2 in brain endothelial cells of rats during endotoxin-induced fever. J Neurosci 21:2669-2677. CrossRef Medline 